Columbia Law School

Scholarship Archive

2008

\title{
The Market for Bad Legal Advice: Academic Professional Responsibility Consulting as an Example
}

\author{
William H. Simon \\ Columbia Law School, wsimon@law.columbia.edu
}

Follow this and additional works at: https://scholarship.law.columbia.edu/faculty_scholarship

Part of the Business Organizations Law Commons, and the Legal Ethics and Professional Responsibility Commons

\section{Recommended Citation}

William H. Simon, The Market for Bad Legal Advice: Academic Professional Responsibility Consulting as an Example, 60 STAN. L. ReV. 1555 (2008).

Available at: https://scholarship.law.columbia.edu/faculty_scholarship/862

This Article is brought to you for free and open access by the Faculty Publications at Scholarship Archive. It has been accepted for inclusion in Faculty Scholarship by an authorized administrator of Scholarship Archive. For more information, please contact scholarshiparchive@law.columbia.edu. 


\title{
ARTICLES
}

\section{THE MARKET FOR BAD LEGAL ADVICE: ACADEMIC PROFESSIONAL RESPONSIBILITY CONSULTING AS AN EXAMPLE}

\author{
William H. Simon*
}

Clients demand bad legal advice when legal advice can favorably influence third-party conduct or attitudes even when it is wrong. Lawyers supply bad legal advice most readily when they are substantially immunized from accountability to the people it is intended to influence. Both demand and supply conditions for a flourishing market are in place in several quarters of the legal system. The resulting practices, however, are in tension with basic professional and academic values. I demonstrate these tensions through critiques of the work of academic professional responsibility consultants in such matters as Enron, Lincoln Savings $\&$ Loan, and a heretofore undiscussed aggregate litigation settlement. I also suggest reforms to reduce the incentives and pressures for bad advice that now prevail.

INTRODUCTION.

I. THE PROBLEM OF QUASI-THIRD-PARTY ACADEMIC ADVICE........................1558

A. Defining the Problem ................................................................. 1558

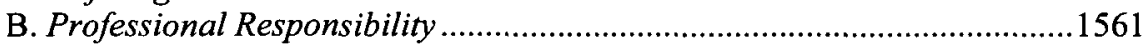

1. Lessons from tax practice ....................................................... 1562

2. An Illustration: Charles Wolfram on Vinson \& Elkins (Enron)..........1567

C. Academic Responsibility

II. A CASE STUdy: ETHICS EXPERTS AND DEFENDANT PAYMENTS To

PLAINTIFFS' LAWYERS IN AGGREGATE LITIGATION ....................................1576

A. Factual Background ................................................................... 1578

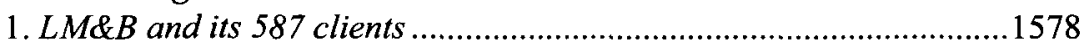

2. The aggregate settlement agreement (DRSA) ....................................1579

a. LM\&B agrees to deliver client agreements and to process claims speedily

b. Nextel agrees to pay LM\&B \$7.5 million .................................. 1580

c. LM\&B agrees to refuse to represent or refer other claimants .......1581

* Arthur Levitt Professor of Law, Columbia University. 
d. Clients are forbidden to discuss claims with each other or anyone else except professional advisors 1581

e. Clients are obliged to stay with LM\&B, and LM\&B is prohibited from associating outside counsel

3. The individual agreements and the ADR process ..............................1582

a. Most clients agree after consultation with LM\&B .......................1582

b. Claims are "resolved" ...............................................................1583

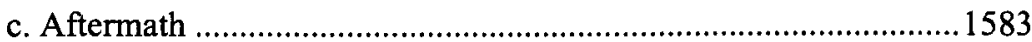

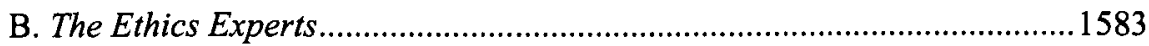

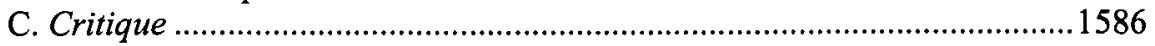

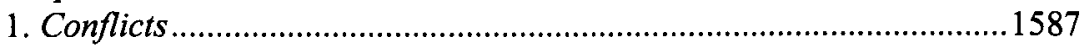

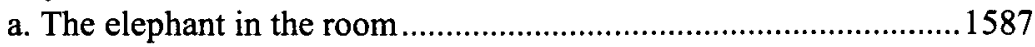

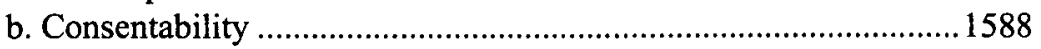

c. Consent after consultation ........................................................1590

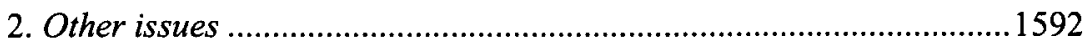

a. Reasonableness of the fee.........................................................1592

b. The clients' commitment to stay with LM\&B ...............................1592

c. The agreement not to accept or refer other claims.........................1593

d. The "consultancy" as a restriction on practice ................................1594

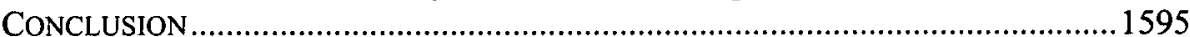

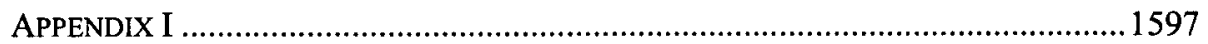

\section{INTRODUCTION}

On several notorious occasions in recent years, lawyers gave clients bad legal advice because the clients wanted it.

Lawyers from Andrews Kurth and from Vinson \& Elkins gave opinions to Enron that various asset transfers represented "true sales" or involved a "true issuance" of securities even though the opinions were either plainly wrong or plainly irrelevant to the circumstances they addressed. ${ }^{1}$

Lawyers at Jenkins \& Gilchrist gave hundreds of opinions to taxpayers to the effect that bizarrely complex and economically substanceless transactions with names like COBRA (Currency Options Bring Reward Alternatives) were acceptable ways to reduce taxes. Some of them were virtually copies of transactions that the IRS had specifically condemned. ${ }^{2}$

John Yoo, Jay Bybee, and other lawyers at the Department of Justice gave opinions to federal officials concluding that various statutory and international law constraints on the President in the "war on terror" were unconstitutional or otherwise not binding. The opinions exaggerated the authority for the conclusions and omitted inconsistent arguments and precedent. ${ }^{3}$

1. See Appendix C (Role of Enron's Attorneys) to Final Report of Neal Batson, CourtAppointed Examiner, at 26-90, In re Enron Corp., 370 B.R. 583 (Bankr. S.D.N.Y. 2007) (No. 01-16034) [hereinafter Batson Report].

2. Paul Braverman, Helter Shelter, AM. LAW., Dec. 2003, at 65. (2006).

3. See generally José E. Alvarez, Torturing the Law, 37 CASE W. RES. J. INT'L L. 175 
In all these cases, the clients seemed happy to get the bad advice, at least in the short term and sometimes in the long term. They were happy because the advice made it easier for them to do things they wanted to do-overstate income on financial statements, underpay taxes, or torture people.

The bad advice made life easier for the clients because, regardless of its merit, it conferred on them a significant measure of immunity from liability or public criticism. In the corporate area, a legal opinion may raise the bar for a shareholder action by satisfying a condition for the "due diligence" defense or the "business judgment" rule. In the tax area, a lawyer's opinion may help establish the "good faith" and "reasonable cause" that enables a taxpayer to avoid penalties for underpayment. And opinions often make the "advice of counsel" excuse available either as a response to a liability claim or a persuasive argument in the court of public opinion.

This capacity to influence public authority or public opinion does not fit easily within the most prevalent understanding of the lawyer's role. Influence of this kind requires the lawyer to purport to speak impartially, rather than as a partisan. Moreover, when the lawyer advises a client, she is normally subject to strong legal mechanisms of accountability to the client. Yet, the lawyer is not comparably accountable to the ultimate public addressees of the advice in our examples.

The public dimension of this advice-giving/immunity-conferring role might seem more appropriate for academic lawyers. Academic lawyers can represent clients in a conventional partisan fashion, but when they express views in their academic roles, the norms of the academy require that they speak sincerely and disinterestedly. From an academic point of view, however, there is a distinctive problem with advice designed to confer immunity. The norms of the academy regard openness and transparency as an essential guarantee of the reliability of a scholar's views. Yet, exonerating opinions are most often subject to conditional secrecy. Typically, the client wants to keep the advice confidential unless she needs to reveal it in order to respond to some challenge to her conduct, and even then, she may want to limit disclosure to a minimum. Thus, the academic lawyer is also in an anomalous position. She invokes the authority of her role and institution as emblems of both acuity and impartiality; yet she forswears the norms of openness that the academic world regards as essential to such claims.

This Article is about legal advice in which lawyers purport to speak disinterestedly in order to influence public conduct or attitudes for the benefit of private clients, and which is given under conditions of nonaccountability and secrecy. I call such efforts "quasi-third-party advice." The Article focuses on the issues of professional and academic integrity raised by quasi-third-party opinions on legal ethics issues by academic lawyers. Much of it also applies to nonacademic lawyers in their opinion practices. And much of it applies as well to nonlawyer academics who give opinions with legal consequences, for example, as expert witnesses in litigation. 
I argue that quasi-third-party opinion practice in its currently prevalent form is inconsistent with core professional and academic values. The key problem does not lie in the assumption of public responsibility by lawyers or in the fact that academics consult for money for private clients. Rather, from both professional and academic perspectives, the key problem lies in the absence of transparency.

Part I elaborates on the issues posed by quasi-third-party practice, and suggests some appropriate responses in terms of both professional and academic ethics, using as examples opinions given by Charles Wolfram of Cornell in connection with Vinson \& Elkins's work for Enron and by Geoffrey Hazard of the University of Pennsylvania in connection with the Kaye Scholer firm's work for Lincoln Savings \& Loan.

Part II further illustrates the problem with a case study. In this case, three prominent academics-Geoffrey Hazard, Roy Simon of Hofstra, and Bruce Green of Fordham-gave bad legal advice with potentially large public consequences. The case involved a non-class aggregate litigation campaign of a kind that involves many claimants and raises important issues of procedure and ethics, but that typically eludes public view through confidentiality agreements. ${ }^{4}$ The academic professional responsibility experts played important roles as enablers of pernicious (and heretofore largely undiscussed) practices. Thus, the case shows the convergence of an underground of litigation practice with an underground of academic practice-practitioners and academics allying under terms designed to immunize each other from accountability.

When I say that the three academics gave "bad legal advice," I am being provocative. My opinions are different from theirs. However, the value of the case study does not depend on whether I am right about the merits. The important contribution is to show that the form such advice takes and the conditions under which it is given reflect pressures and incentives that undermine confidence in its reliability.

\section{THE Problem OF QuASI-THIRD-PARTY ACADEMIC ADVICE}

\section{A. Defining the Problem}

We are interested in advice by academic lawyers that has two characteristics: first, it has an externality in the form of an influence on thirdparty conduct or attitude for which the advisor is not strongly accountable, and second, it is subject to significant secrecy.

4. See Howard M. Erichson, Beyond the Class Action: Lawyer Loyalty and Client Autonomy in Non-Class Collective Representation, 2003 U. CHI. LEGAL F. 519 (2003); David Luban, Settlements and the Erosion of the Public Realm, 83 GEO. L.J. 2619, 2647-59 (1995). 
The relevant measure of strong accountability is the common law duty of care that a lawyer owes a client when giving first-party advice. The lawyer is sometimes charged with a comparable duty to addressees of certain traditional third-party opinions. For example, major financing agreements often require that the borrower's lawyer provide an opinion addressed to the lender attesting to various matters, such as that the borrower is duly authorized to enter the agreement. Doctrine generally recognizes a duty of care comparable (at least in principle) to that owed a client. ${ }^{5}$

By contrast, quasi-third-party advice may not be directly addressed to third parties. Often, although there is a tacit understanding that the client will show the opinion to third parties if he needs to, the client is the only explicit addressee. In other cases, the opinions are addressed directly to third parties, but the addressees are too diffuse or remote to satisfy the privity requirements for strong duties.

Take the "advice of counsel" excuse. A client who receives advice that a course of conduct is lawful can sometimes escape liability, even when the advice proves wrong. At the extreme, such advice can amount to "get-out-ofjail-free cards," as Jack Goldsmith characterizes certain Office of Legal Counsel opinions. ${ }^{6}$ Where bad advice causes the client to incur liability, the advisor will often be liable to the client. But where the bad advice helps the client escape liability, the advisor has no comparable accountability to the officials or members of the public who bear the costs of the bad advice.

Sometimes the advisor will have some accountability to the third parties, but it will be weaker than a full-fledged duty of care. For example, lawyers owe a duty to public shareholders not to assist managerial fraud under the securities laws, but under the Central Bank of Denver case, ${ }^{7}$ that duty cannot be enforced through private damage actions. Or to take another context central to our inquiry, the expert litigation witness owes a duty of candor to the court, but the only enforceable form of that duty is the perjury statute, and perjury is hard to prove in the case of opinions. There is no liability for negligence or

5. E.g., Greycas v. Proud, 826 F.2d 1560 (7th Cir. 1980). But see Jonathan M. Barnett, Certification Drag: The Opinion Puzzle and Other Transactional Curiosities, 33 J. CoRP. L. 95, 112-18 (2007) (pointing out that courts seem more reluctant to enforce the duty in the third-party than in the first-party context).

6. JACK GOLDSMITH, THE TERROR PRESIDENCY 97 (2007); see also Randolph D. Moss, Executive Branch Legal Interpretation: A Perspective from the Office of Legal Counsel, 52 ADMIN. L. REV. 1303, 1318-20 (2000) (discussing views on the binding effect of OLC opinions). The exculpatory effect of advice from private counsel is more limited, but a substantial effect is recognized with respect to both civil and criminal claims requiring proof of willfulness or bad faith. See, e.g., Mahurker v. C.R. Bard, 79 F.3d 1572, 1579 (Fed. Cir. 1996) (stating that advice of counsel may provide a defense to a claim of willfulness in patent infringement case); United States v. Baldwin, 307 F.2d 577, 579 (7th Cir. 1962) (noting that advice of counsel may show lack of intent in tax fraud case).

7. Cent. Bank of Denver v. First Interstate Bank of Denver, 511 U.S. 164 (1994). 
recklessness. ${ }^{8}$

The second defining condition of our subject is secrecy. It might seem that exonerating opinions would by their nature be publicly accessible. But this is not the case. Clients often want the advice to remain secret unless and until it is needed, and want the ability to strictly control its distribution afterwards.

Academic lawyers tend to be asked for quasi-third-party opinions in two general contexts. In the ex ante context, the client asks for the opinion before she embarks on the desired conduct. Most often, the client would prefer to hold the opinion in reserve for use in the event of public inquiry. In this context, the lawyer's role will be that of a legal advisor, and traditional attorney-client confidentiality will apply by default.

In the ex post situation, public inquiry is ongoing, and the client asks for exoneration with respect to past conduct (or sometimes, for inculpation with respect to an opposing party's past conduct). Here the academic lawyer is likely to be retained as an expert witness. ${ }^{9}$ The default rule is less clear in this context, ${ }^{10}$ but the prevalent practice is for the client to ask the expert to sign a non-disclosure agreement precluding the expert from any kind of discussion of the case or facts learned from the client without the client's authorization. Occasionally, the client in this context will go public with the expert's opinion, but usually only under tightly controlled circumstances. The client would be more likely to distribute a written statement by the expert vetted by the client or perhaps prepared by the client's lawyers and approved by the expert than to allow the expert to speak spontaneously or to respond to questions or arguments.

In litigation, the expert who is retained to testify begins by preparing a written report, which is given to the opposing party. The expert is then deposed

8. Even liability for perjury cannot be enforced privately. Briscoe v. LaHue, 460 U.S. 325, 330-34 (1983) (reaffirming the traditional common law immunity of witnesses from damage claims). For a survey and critique of the doctrine as applied to experts, see Jeffrey $\mathrm{L}$. Harrison, Reconceptualizing the Expert Witness: Social Costs, Current Controls, and Proposed Responses, 18 YALE J. ON REG. 253 (2001).

9. Courts commonly admit academic opinions on whether challenged lawyer conduct is consistent with professional responsibility norms despite the objection that admission violates the traditional rule against testimony on matters of law. See Carl M. Selinger, The Problematical Role of the Legal Ethics Expert Witness, 13 GEO. J. LEGAL ETHICs 405, 408$18(2000)$.

10. Some cases hold that rules like Federal Rule of Civil Procedure 26(b) impliedly prohibit lawyers from ex parte contact with opposing experts. See 6 JAMES WM. MOORE ET AL., MOORE'S FEDERAL PRACTICE I 26.80[4] (3d ed. 1997). Others have disqualified experts from testifying adversely to former clients in matters related to the former engagement (although in at least some of these cases the expert appears to have acted in the former engagement as a consulting expert, whose work may have been privileged, rather than as a testifying expert). See Great Lakes Dredge \& Dock Co. v. Harnischferger, 734 F. Supp. 334, 336-39 (N.D. Ill. 1990) (discussing cases). These cases might be taken to imply that the testifying expert has a duty of confidentiality even in the absence of agreement, but it is debatable whether such a duty is entailed by or even compatible with the expert's role. See Samuel R. Gross, Expert Evidence, 1991 WIS. L. REV. 1113, 1148-52. 
and finally, if the case gets that far, testifies at trial. One would think that at some point the opinion would become publicly accessible, but this is often not the case. Since discovery materials are rarely filed before trial and most cases do not reach trial, the expert's report and deposition often do not become part of the case record. Even when there is a trial and the expert testifies, the record is often accessible only at considerable expense and inconvenience. And many settlements provide for the record to be sealed. Thus, as a practical matter, the expert's opinions are often inaccessible.

Secrecy removes another mechanism of lawyer accountability. An academic who repeatedly gave bad advice in public would suffer serious loss of prestige in the academic world, especially if she was doing it in the pay of interested parties. Consider the academic reputations of scientists who have publicly disputed global warming or tobacco toxicity under the patronage of the energy or cigarette industries. But as Samuel Gross puts it, "what an expert says in court [and a fortiori, in ex ante opinions] is generally invisible and inaudible in her own professional field." 11

Similarly, the exoneration or inculpation potential of bad advice from a lawyer with a reputation for giving bad advice consistently would be small. But the public and public officials know nothing about most such opinions and rarely know enough about them to form a judgment about their plausibility.

\section{B. Professional Responsibility}

Professional responsibility norms recognize strong duties of care and loyalty to clients and modest duties of respect for law to strangers and the public. The strong duties require the lawyer to take initiative to acquire information and make disclosures to protect the client's interests. The modest duties characteristically do not require initiative or affirmative disclosure; they are usually satisfied when the lawyer refrains from misrepresentation and complies with clear legal commands.

There has been some recognition that this doctrinal structure is inadequate in the situation where the lawyer gives advice meant to produce the third-party effects with which we are concerned. An early step in this direction was the application of the "due diligence" idea to lawyers in the securities context. Lawyers tend to think of "due diligence" as a streamlined duty of care to securities investors. The duty is not as strong as a full-fledged fiduciary duty to a client, but it is stronger than conventional duties to strangers. ${ }^{12}$

11. Gross, supra note 10 , at 1178 .

12. See Thomas Lee Hazen, The Law of Securities Regulation $\$ 7.4$ (4th ed. 2002). Strictly speaking, "due diligence" is a defense to a fraud claim. However, the securities laws developed a particularly demanding version of fraud liability which sometimes treats failure to disclose as misrepresentation and failure to learn as tantamount to knowledge. The net effect is that of an enhanced duty. 


\section{Lessons from tax practice}

The most ambitious response has occurred in the tax area. The IRS and some groups within the tax bar have become concerned about the effects on legal advice of the two phenomena I have singled out-third party effects and secrecy. The principal third-party effect arises from "penalty protection." The taxpayer can often avoid a penalty for underpayment if she can show "reasonable cause" and "good faith,"13 and an opinion is a key part of the usual showing. Secrecy arises in part from the fact that there is often a high probability that the IRS will never identify the questionable maneuver. The issue may not be apparent except on searching examination of the return, and the IRS fails to examine most returns more than superficially. If the issue is never identified, the IRS never learns about it. Moreover, when promoters have marketed aggressive tax shelters in recent years, they have typically insisted on strict confidentiality commitments from their clients.

The tax sections of the American Bar Association and the New York State Bar Association have written insightfully about the threats to professional responsibility posed by this situation. A key report from the New York section identifies the problem as an inversion of the traditional professional understanding of the nature and effect of legal advice. The bar assumes that legal advice is a social good because it tends to induce compliance with law. ${ }^{14}$ Where, however, legal advice affords exoneration independently of its merit, there is demand for bad advice, which induces socially undesirable behavior. The report worries about the reciprocal corrosion of client motivation and professional morale when the focus of the "tax dialogue" between lawyer and client shifts from the requirements of law to "whether an opinion will be rendered or not." The section urges reforms designed to restore clients' incentive to seek "the most thoughtful and accurate legal advice [rather than] the most aggressive." 15

Congress and the IRS have responded to the problem by producing a new set of norms for tax practice enforced by financial penalties and IRS disciplinary sanctions. The regime focuses especially on opinions with thirdparty effects-what the IRS calls "reliance opinions" intended to be used for penalty protection and "marketing opinions" given to promoters for use in selling shelter advice to corporate and high-income individual customers.

13. 26 U.S.C.A. $\S 6664(c)(1)$ (2006).

14. See, e.g., MOdEl Rules Of PROF'L CONDUCt R. $1.6 \mathrm{cmt}$. (2002).

15. N.Y. State Bar Ass'n TAX Section, Report on Corporate TaX Shelters of New York State Bar Association Tax Section (1999), reprinted in NYSBa Tax Section Applauds Some Anti-Corporate Tax Shelter Proposals, Rejects Others, 1999 TAX NotEs 82 29, If 101 (Apr. 29, 1999). Tanina Rostain was the first to draw attention to the general importance of the work of the New York and ABA tax sections, see Tanina Rostain, Sheltering Lawyers: The Organized Tax Bar and the Tax Shelter Industry, 23 YALE J. ON REG. 77 (2006). I am grateful to Dennis Ventry for helpful discussion of the regulation of tax practice. 
Some of the provisions aim to limit the conditions of third-party effects or secrecy that produce the demand for bad legal advice; some focus on the supply side by imposing requirements on the production of quasi-third party opinions. On the demand side we find rules conditioning penalty protection on disclosure. Since the American Job Creation Act of 2004, penalty protection in connection with certain shelter-like "reportable transactions" requires "disclosure" of the transaction on the return. ${ }^{16}$ In addition, opinions by lawyers who participated in developing the transaction or were compensated by promoters cannot be used for this purpose. ${ }^{17}$ Moreover, lawyers advising with regard to such transactions must produce a list of clients to the IRS on demand, thus making it likely that all will be audited if any are discovered. ${ }^{18}$ Most radically, lawyers who advise with regard to some shelter-like transactions have to report the advice to the IRS on an information return. ${ }^{19}$

The second category of principles governs the content of tax opinions likely to have third-party effects. These principles have been promulgated by the Treasury Department in regulations known as "Circular 230."20 Although expressed in a distinctive rhetoric and format, they can be usefully summarized in terms of five broad norms: candor, clarity, due diligence, analytical support, and reasonable framing. If complemented by one further principle-updatingthey could provide a plausible starting point for a general approach to quasithird-party opinions.

Candor. The lawyer has to explain her own role, and in particular, any interest or stake she has in the matter on which she opines. ${ }^{21}$ For example, if she helped design the transaction or if her compensation is contingent on the taxpayer's success in realizing the tax benefits, she must disclose that.

Clarity. The lawyer has to be clear both about the issues on which she is opining and about the strength of her conclusion. A general statement to the effect that a transaction is "appropriate" is objectionable in two respects. First, it may not be clear which issues and potential objections have been considered and rejected. Circular 230 deals with this problem by requiring the lawyer to opine on every material tax issue or to identify any excluded issues and explain why the opinion excludes them. ${ }^{22}$

16. 26 U.S.C.A. $\S \S 6662,6664(\mathrm{~d})(2)(A)$ (2006). A weaker but still important safeguard is the evidence doctrine that once a client asserts "advice of counsel" as an excuse, she waives privilege with respect to all advice on the relevant subject matter. In re Echostar Commc'ns Corp., 448 F.3d 1294, 1299 (Fed. Cir. 2006). Thus, a client cannot produce a favorable opinion while asserting privilege with respect to unfavorable ones.

17. 26 U.S.C.A. $\$ 6664(\mathrm{~d})(3)(B)(2006)$.

18. 26 U.S.C.A. $\$ 6112(\mathrm{a})(1)(2006)$.

19. 26 U.S.C.A. $\$ 6111$ (a)-(b) (2006).

20. 31 C.F.R. pt. 10 (2007). These regulations were influenced by an ABA ethics committee opinion proposing distinctive standards for shelter opinions with third-party effects. ABA Comm. on Ethics and Prof'l Responsibility, Formal Op. 346 (1982).

21. 31 C.F.R. $\S 10.35(\mathrm{e})(1)-(2)(2007)$.

22. 31 C.F.R. $\S 10.35(c)(3)-(4)(2007)$. 
Second, it may be unclear what kind or level of conviction the lawyer is asserting. When an advocate asserts a position on behalf of a client, she typically implies no personal conviction beyond a belief that the position is not frivolous. ${ }^{23}$ When the lawyer opines as an expert to third parties, she is usually taken to connote a higher threshold of conviction.

But what is this threshold? The expert's opinion is generally understood to express what he believes to be the "best" understanding of the relevant law. But of course, the expert can hold a view about the best understanding at various levels of confidence. Moreover, an expert conclusion typically combines (a) the expert's view of how the issue would be resolved by those with ultimate authority over the matter and (b) his view of how the issue should be resolved (for example, how the expert would resolve it himself if he were in authority). Most lawyers' understanding of disinterested legal judgment combines both these elements, but there is disagreement about their relative weights. How important such disagreements are depends on how idiosyncratic the opiner's own substantive views are. If the opiner's views are mainstream, then her understandings of how the issue would be resolved and how it should be resolved will tend to converge. Even where the opiner's views are idiosyncratic, the stakes with respect to these matters may not be that great as long as the opiner makes clear what approach she is taking and explains the ways in which her substantive convictions are idiosyncratic.

Consider the "torture memos." If a client had asked for a memo setting out the strongest legal arguments that could be made in favor of the administration's interrogation practices for suspected enemy combatants, it would be reasonable for a lawyer to respond with analyses such as those in the memos. The problem, of course, is the memos were not styled as advocacy, but as expertise. They purported to set out, ex officio, the views of the Office of Legal Counsel. In this context, the memos might still have been acceptable if the authors had made clear that they were setting forth the positions they would take if they had ultimate authority to apply the law, while making clear how and why their views were idiosyncratic. But they failed to do this. ${ }^{24}$

Circular 230 has a plausible clarity-forcing measure. A tax lawyer has a duty in giving an opinion with third-party effects to give a "more likely than not" conclusion or explain why she cannot give such a conclusion. "More likely than not" means a belief that the probability exceeds fifty percent that a well-informed official or tribunal with ultimate authority over the matter would adopt the position in question. ${ }^{25}$ At the same time, the rule makes clear that the expert should give a normative rather than a predictive judgment. The opiner is

23. See Model Rules of Prof'L Conduct R. 3.1 (2002).

24. Yet another interpretation might see the torture memos as an exercise of legislative rule-making power to immunize the conduct they consider. See Moss, supra note 6, at 1319. Assuming the OLC has such power, the objection would remain that the memos purport to be analyzing pre-existing authority, not making law.

25. 31 C.F.R. $\S 10.35$ (c)(3)(ii) (2007). 
specifically precluded from considering the likelihood that the transaction will actually be officially reviewed-the likelihood of audit. ${ }^{26}$ "More likely than not" is a heuristic designed to specify a level of confidence and a jurisprudential perspective that gives greatest weight to established authority and mainstream modes of argument over idiosyncratic substantive interpretation.

Due Diligence. Circular 230 takes over the principle associated with securities regulation that lawyers cannot accept clients' characterizations or conclusions without inquiring into underlying facts and, when they have reason to doubt the client's report of material facts, must demand substantiation. ${ }^{27}$ The core example in tax is the client's assertion that some tax avoidance transaction has a non-tax "business purpose." Before the lawyer can assume such a conclusion, she must be given basic facts that are at least facially plausible to support it.

Analytical support. Under Circular 230, "[t]he opinion must relate the applicable law ... to the relevant facts. ${ }^{28}$ Quasi-third-party opinions should be reasoned opinions. The lawyer may not set forth critical nonobvious legal propositions as conclusions supported only by her reputation and credentials.

Reasonable framing. The lawyer cannot unreasonably exclude issues that are material to the client's purpose and within her expertise. In particular, she cannot pick out those issues on which she can support a favorable view while ignoring the rest. ${ }^{29}$ This principle would condemn the fairly common practice in financial transactions of stating conclusions broadly and then proceeding to qualify them virtually out of existence. ${ }^{30}$ At least, it would require clear identification of the omitted issues and an explanation of why they cannot be addressed.

Updating and correction. Finally, I would add a sixth standard that does not appear in Circular 230 but should be part of any set of principles of quasithird-party opinions: a duty to update in the light of new information where there is continuing reliance on the opinion.

In general, the bar has tended toward the position that the default rule in conventional third-party opinions should be that there is no duty to update. ${ }^{31}$

26. 31 C.F.R. $\S 10.35$ (c)(3)(iii) (2007).

27. 31 C.F.R. $\S \S 10.22,10.35$ (c)(1) (2007).

28. 31 C.F.R. $\$ 10.35(\mathrm{c})(2)(2007)$.

29. 31 C.F.R. $\S 10.35$ (c)(3)(ii) (2007).

30. Barnett, supra note 5, at 98-99. Vinson \& Elkins's "true issuance" opinions for Enron were qualified by the assumption that a court would not recharacterize the transactions in question as loans (rather than sales). Since the whole point of the opinions was to justify accounting treatment that depended entirely on the correctness of this assumption, the opinions were disclaiming responsibility for the only issue that was material to their purpose. Batson Report, supra note 1, at 23, 34-35.

31. ABA Comm. on Legal Opinions, Third-Party Legal Opinion Report, 47 Bus. LAw. $167, \S 9$, at 196-97 (1991). 
Where the third-party opinion is given on behalf of a client, the bar has interpreted confidentiality duties to the client to preclude correction without the client's consent.

This situation changed somewhat following the OPM scandal of the 1970s. OPM was a computer leasing company that financed itself by borrowing on the collateral of its leases. For a period, it was closing loans with some of the nation's biggest banks every few months. In each round of lending, its lawyers gave opinions to lenders asserting that the relevant leases were valid and enforceable. When the lawyers discovered that the client had forged many of the leases, they remained silent, relying partly on the advice of an ethics expert that they were precluded from warning the lenders. ${ }^{32}$

The bar became concerned that denial of even the option to correct would put the lawyer at risk of liability under common law fraud principles. The common law sometimes requires correction where a person discovers that a statement he previously made in good faith is false. ${ }^{33}$ The bar thus reinterpreted its rules to allow a lawyer without client consent to engage in "noisy withdrawal" from the client by "disavowing" the opinion to the third party. ${ }^{34}$ The newest version of the ABA Model Rules of Professional Conduct explicitly permits any disclosures that would mitigate or rectify the effects of client fraud in which the lawyer was involved. ${ }^{35}$

The case for a duty (not just the permission the $\mathrm{ABA}$ rules give) to update in the quasi-third-party situation is strong. The purpose of such opinions is to induce third-party reliance; so the opiner should be responsible as long as such reliance continues. The ultimate addressees of quasi-third-party opinions, unlike those of conventional third-party opinions, are not in a position to bargain for such a duty; so if they are to have this protection, it must be mandated. Moreover, once the client goes public and presents the lawyer's opinion as expertise (rather than advocacy), it has waived any plausible claim to confidentiality. ${ }^{36}$

32. For the story of OPM, see Stuart Taylor, Jr., Ethics and the Law: A Case History, N.Y. TIMES, Jan. 9, 1983, $\S 6$ (Magazine), at 31 . The relevant rules then (as now) plainly permitted warnings of ongoing fraud.

33. See, e.g., RESTATEMENT (SECOND) OF TORTS $§ 551(2)(d)$ (1977).

34. ABA Comm. on Ethics and Prof'I Responsibility, Formal Op. 92-366 (1992).

35. MOdEL RULES OF PROF'L CONDUCT R. 1.6(b)(3) (2002).

36. Circular 230-type standards are designed primarily for ex ante opinions. They may require some softening in the litigation context. A less demanding standard of "due diligence" might seem appropriate where the expert's factual assumptions will be subject to adversarial challenge and demands for evidentiary support. It might also seem appropriate to leave the parties more discretion to choose and shape issues when opposing lawyers and experts stand ready to fill any lacunae. Still, the basic standards of clarity, candor, and reasoned explanation apply. Moreover, one should not overestimate the power of the adversarial process to neutralize the defects of opinion evidence. Most cases are settled, and I have heard more than one academic expert justify large retainers on the ground that the mere announcement that he has agreed to testify substantially increases the settlement value of the client's claim. Such assertions imply an influence that could readily be abused despite 


\section{An Illustration: Charles Wolfram on Vinson \& Elkins (Enron)}

As an illustration of how these principles might be applied outside the tax area, consider the opinion reprinted in Appendix I that Charles Wolfram of Cornell gave with regard to Vinson \& Elkins's (V \& E) representation of Enron. The opinion addressed V \& E's role in Enron's response to the letter written by the in-house accountant Sherron Watkins to CEO Ken Lay in August 2001. Watkins warned that Enron might "implode in a wave of accounting scandals" and drew particular attention to a set of transactions known as "the Raptors." 37 These were ostensibly "hedge" transactions intended to obviate recognition of declines in value of certain merchant investments on Enron's income statements. In fact, they were not hedges in any functional sense; they did not affect Enron's exposure to risk or reward with respect to the investments. (In the Orwellian rhetoric of notes made at a meeting of the board's finance committee, "Does not transfer economic risk but transfers P\&L [income statement] volatility." ${ }^{38}$ ) Watkins made two points about the Raptors: They amounted to accounting fraud, and they involved large, unjustifiable payments to Enron's chief financial officer Andrew Fastow.

Watkins urged an investigation and specifically warned that Enron's regular outside counsel, Vinson \& Elkins, should not be used: "Can't use V \& $\mathrm{E}$ due to conflict-they provided some true sale opinions on some of the deals." ${ }^{.39}$ Nonetheless, Enron's general counsel and V \& E decided that the latter would conduct the investigation. The investigation was to be a "preliminary investigation" to see if a broader one would be warranted. ${ }^{40}$ Moreover, the investigation was not to involve "second guessing" of judgments made by Arthur Andersen, Enron's auditors, or Enron's board, but merely an effort to determine whether Watkins had any material information that these

adversarial checks. For a discussion of the problems of expert testimony and a range of possible responses, see Gross, supra note 10; Harrison, supra note 8.

37. Memorandum from Sherron Watkins, Former Vice President for Corp. Dev., Enron Corp., to Kenneth Lay, Former CEO and Chairman, Enron Corp. (Aug. 2001), reprinted in Destruction of Enron-Related Documents by Andersen Personnel: Hearing Before the Subcomm. on Oversight and Investigations of the Comm. on Energy and Commerce, 107th Cong. 39-44 (2002), available at http://republicans.energycommerce. house.gov/107/action/107-80.pdf [hereinafter Watkins Memorandum].

38. SPECial InVESTigative COMMITTEe of THE BoARD OF Directors of ENRON CORP., REPORT OF INVESTIGATION 106 (2002), available at http://fll.findlaw.com/ news.findlaw.com/hdocs/docs/enron/sicreport/sicreport020102.pdf [hereinafter ENRON INVESTIGATIVE COMMITTEE REPORT]

39. Watkins Memorandum, supra note 37, at 43.

40. Letter from Max Hendrick III, Vinson \& Elkins LLP, to James Derrick, Executive Vice President and General Counsel, Enron Corp. (Oct. 15, 2001), reprinted in Destruction of Enron-Related Documents by Andersen Personnel: Hearing Before the Subcomm. on Oversight and Investigations of the Comm. on Energy and Commerce, 107th Cong. 46-54 (2002), available at http://republicans.energycommerce.house.gov/107/action/107-80.pdf [hereinafter V \& E Letter]. 
decisionmakers were unaware of when they made their decisions. ${ }^{41}$ The lawyers concluded that there was no new information and reported back in a letter dated October 15, 2001, that Watkins's letter gave no cause for concern or more extensive investigation. ${ }^{42}$

By this time, however, Enron was imploding in the manner Watkins predicted. As the collapse became visible, the board appointed a committee of independent directors, which in turn hired new counsel, who in turn retained new accountants as consultants. The result was the "Powers Report" released in February 2002, analyzing and documenting a large number of improper accounting maneuvers and self-dealing transactions, including the Raptors, of the sort Watkins had identified. The Powers Report was critical of V \& E on many fronts. With respect to the response to the Watkins letter, it wrote, "The result of the $\mathrm{V} \& \mathrm{E}$ review was largely predetermined by the scope and nature of the investigation and the process employed. ${ }^{, 43}$ In particular, it faulted V \& E for failing to seek review of relevant accounting judgments by unbiased accountants, for speaking only to a limited number of senior Enron people, most of whom "had substantial professional and personal stakes in the matters under review," and for conducting the review with "less skepticism than was needed." 44

V \& E retained Williams \& Connolly to represent it in connection with Enron-related liability, and Wolfram delivered to the firm a letter dated just six weeks after the Powers Report opining on V \& E's conduct in the Watkins investigation. The letter has been circulated widely but selectively. It has been referred to in the press and cited in law review articles, and it has been shown to parties in Enron litigation as an indication of testimony that Wolfram might give on V \& E's behalf. ${ }^{45}$ On the other hand, it has never been generally released, and when I asked for a copy in 2003, I was refused.

Wolfram begins by saying he is responding to a request for his opinion on "whether Vinson \& Elkins acted appropriately in undertaking for Enron a preliminary investigation" in response to the Watkins letter. ${ }^{46} \mathrm{He}$ then states his conclusion that the firm acted "both properly and ethically." The opinion, he tells us, is based on the facts set out in V \& E's letter to Enron on its investigation and the Powers Report.

About half of the four-page letter recites facts from V \& E's letter. Along the way, Wolfram opines that it is "customary and appropriate" for a company to conduct a "preliminary investigation" before undertaking a "full scale" one;

41. Id. at $46-47$.

42. Id. at 53-54.

43. ENRON INVESTIGATIVE COMMITTEE REPORT, supra note 38 , at 176.

44. Id. at 177.

45. See, e.g., Roger C. Cramton, Enron and the Corporate Lawyer: A Primer on the Legal and Ethical Issues, 58 Bus. LAw. 143, 166 n.109 (2002); Mike France, Can Law Profs Consult-and Keep Their Distance?, Bus. WK., Feb. 2, 2004, at 71.

46. The Wolfram letter is transcribed infra at Appendix I. 
that $\mathrm{V} \& \mathrm{E}$ had no preclusive conflict of interest by virtue of having worked on the transactions Watkins questioned because Watkins's concerns focused on "business and accounting" issues and thus V \& E "would not be sitting in judgment of its own legal services"; that V \& E's prior receipt of large fees from Enron did not create a conflicts problem; and that V \& E "could properly accept the judgment of the accountants, Board members, employees, and officers in reaching its conclusions."

Measured by the standards discussed above, the letter is unsatisfactory in at least four respects.

Clarity. The letter is ambiguous about how broadly its claim that V \& E acted "appropriately" should be understood. Wolfram does clearly (and as we will see, wrongly) reject Watkins's claim that V \& E had a conflict under the professional responsibility rules that affected its ability to undertake any investigation into Watkins's concerns. But beyond that his intentions are mystifying. The Powers' Report's most important criticisms were that V \& E should have sought new accounting advice and interviewed more widely, especially people not dependent on Andrew Fastow. Are we to understand by Wolfram's general endorsement of V \& E's conduct as "appropriate" and his statement that V \& E "could properly accept the word of the officers of its client and rely on the judgment of the accountants, Board members, employees, and officers" that he rejects this complaint? Surely he cannot be saying that that a lawyer investigating allegations of corporate wrongdoing can accept conclusory reassurances from the alleged wrongdoers. If this is not the principle, then what is? The Powers Report tells us, for example, that V \& E failed to interview former employees (from whom one might expect more candor than current ones), including two recommended by Watkins, that it never sought to find out how much Fastow profited from the self-dealing transactions, and that it failed to discover serious lapses in the Board oversight process for related-party dealings. ${ }^{47}$ Is Wolfram opining that such failures are consistent with a competent investigation? If so, is he doing so just as a matter of professional responsibility, or also as a matter of corporate law or the customary duty of care for a business lawyer? The letter gives no indication.

Reasonable framing. Wolfram's most salient contention-repeated in three variations-is that, "Before initiating such an independent investigation, it is customary and appropriate for a corporation to conduct a preliminary inquiry to determine whether such an independent investigation is warranted." Yet, this conclusion merely raises the further question of whether information $\mathrm{V} \& \mathrm{E}$ acquired or should have acquired in the "preliminary" investigation should have led it to recommend a full-scale one. Wolfram offers no consideration of this question. The focus on the permissibility of a "preliminary" investigation simply sidesteps the main criticism of the Powers Report, which is that there

47. ENRON INVESTIGATIVE COMMITTEE REPORT, supra note 38, at 158-65. On Watkins's recommendation, see Batson Report, supra note 1, at 166. 
should have been more investigation than there was.

Supporting analysis. The one opinion clearly expressed in the letter is that $\mathrm{V} \& \mathrm{E}$ did not violate professional responsibility rules on conflicts of interest by undertaking the investigation. Yet, this opinion is explained only by an assertion that Watkins's letter raised only "issues of business and accounting judgment" and did not concern "the quality of the legal work previously performed for Enron by Vinson \& Elkins." Thus, V \& E "would not be sitting in judgment of its own legal services." This premise is asserted as a conclusion without any analysis or any acknowledgement of alternative views. Yet, it is highly controversial. In my view, it is wrong.

Wolfram adopts V \& E's and Enron management's understanding of their roles with respect to financial reporting. In this view, what goes on a financial statement is governed by accounting rules and the judgments of accountants. Managers and lawyers discharge their responsibility when they transmit material information to the accountants. At least until they have reason to believe the accountants are corrupt or unqualified, they need not reconsider judgments the accountants make.

The problem with this view is that the securities laws preclude any clean separation of accounting and legal judgments. The laws incorporate Generally Accepted Accounting Principles (GAAP), and some GAAP standards, including the one most pertinent to structured finance, in turn incorporate legal rules. ${ }^{48}$ More fundamentally, the laws require that financial statements both comply with GAAP and be "not misleading." Every assertion must comply with the "not misleading" standard, and thus every assertion potentially involves a legal judgment. Judge Henry Friendly spelled this out in a 1969 opinion, the memory of which seems to have been collectively repressed by a broad segment of the securities bar during the 1990s boom. ${ }^{49}$

Watkins was making the same point as Friendly. She conceded that the accounting might be technically correct. ${ }^{50}$ The problem, she said, was that the overall impression obscured information that would "influence [the] investing decisions" of "the man in the street." She called this effect a violation of the "overriding basic principle of accounting," 51 but the overriding basic principle

48. Fin. Accounting Standards Bd., Statement of Financial accounting Standards No. 125: ACCOUNTING FOR TRANSFERS AND SERvicing OF FINANCIAL ASSETS AND EXTINGUISHMENTS OF LIABILITIES app. I 23 (1996) (explaining that proper treatment depends on specified "factors pertinent under applicable law"). See generally Lawrence A. Cunningham, Sharing Accounting's Burden: Business Lawyers in Enron's Dark Shadows, 57 BuS. LAw. 1421, 1436-38 (2002) (noting the pervasiveness of "mixed questions of accounting and law" in business practice and specifically in structured finance).

49. United States v. Simon, 425 F.2d 796, 805-07 (2d Cir. 1969) (holding that compliance with GAAP does not exonerate an otherwise misleading statement); see also HAZEN, supra note 12, § 12.9[9], at 610-11 (same).

50. Batson Report, supra note 1, at 165.

51. Watkins Memorandum, supra note 37 , at 40. 
of securities law is substantially the same. ${ }^{52}$

$\mathrm{V} \& \mathrm{E}$ had been pervasively involved in structuring and documenting the transactions. ${ }^{53}$ The Powers Report made clear that it did so knowing that they had no purpose other than to generate accounting effects that, among other things, would obscure huge declines in the value of Enron's assets. Whether this fact alone made the transactions fraudulent is still debatable, ${ }^{54}$ but there has never been a time when it was reasonable to think that it did not raise a legal issue.

Update. After Wolfram wrote his letter, his Cornell colleague Roger Cramton pointed out in a law review article that whether $\mathrm{V} \& \mathrm{E}$ had a disqualifying conflict with respect to the Watkins inquiry turned, not on the abstract characterization of the issues as accounting or legal, but whether V \& $E$ had reason to fear being sued if the Raptors were determined to be improper. ${ }^{55} \mathrm{~V} \& \mathrm{E}$ 's letter specifically mentioned the possibility of a "class action," 56 and given the firm's pervasive involvement, it should have expected to be named in any such suit. In fact, a class action was brought; V \& $E$ was named; and the court upheld the complaint against V \& E's motion to dismiss, citing Cramton's analysis of the Watkins inquiry issues with approval. ${ }^{57}$

Does Wolfram still hold the views in the letter? How does he respond to his colleague and the court? Wolfram has not told us. Yet, V \& E's counsel continues to distribute the original letter in support of its contention that the firm was blameless.

52. See, e.g., TSC Indus., Inc. v. Northway, Inc., 426 U.S. 438, 449 (1976) (noting that information is material for proxy disclosure purposes when "there is a substantial likelihood that a reasonable shareholder would consider [information] important in deciding how to vote").

53. Batson Report, supra note 1, at 161-62. Watkins, however, was mistaken in saying that the firm had given "true sale" opinions with respect to the "Raptors." Id. at 162.

54. Compare Steven L. Schwarcz, The Limits of Lawyering: Legal Opinions in Structured Finance, 84 TEX. L. REV. 1, 27-28, 31-32 (2005), with William H. Simon, Earnings Management as a Professional Responsibility Problem, 84 TEX. L. REV. 83, 88-91 (2005).

55. Cramton, supra note 45 , at 165-67.

56. V \& E Letter, supra note 40 , at 53.

57. In re Enron, 235 F. Supp. 2d 549, 668 n.103, 704-05 (S.D. Tex. 2002). The plaintiffs in the securities class action agreed to dismiss the claims against $\mathrm{V} \& \mathrm{E}$ in late 2006. Kristen Hays, Law Firm Could Be Cut Free From Suit: Enron Case Plaintiffs Ask To Dismiss V\&E, Hous. CHRON., Dec. 9, 2006. It seems unlikely that this decision implies anything about the issues addressed in Wolfram's opinion. The largest obstacle to recovery was the doctrine that there is no private right of action for aiding and abetting, as opposed to primary, securities fraud. Cent. Bank of Denver v. First Interstate Bank of Denver, 511 U.S. 164 (1994). Although not privately redressable under federal law, aiding and abetting securities fraud is a (publicly enforceable) wrong under the securities laws, as well as under professional responsibility rules, MODEL RULES OF PROF'L CONDUCT R. 1.2(d) (2002). It is also a privately enforceable wrong at common law. See RESTATEMENT (SECOND) OF TORTS $\S 876($ a) (1977). 


\section{Academic Responsibility}

When academic professionals give quasi-third-party opinions, they raise issues of academic as well as professional responsibility.

University policies typically require both candor and openness with respect to academic work. ${ }^{58}$ Recent discussion has treated as especially sensitive situations in which outside funders with a private stake in a subject exert control over disclosure. ${ }^{59}$

However, the issues raised by quasi-third-party opinions do not fall squarely within typical current research policy norms. Norms with respect to candor typically apply to university faculty in any conduct in which their University affiliation is salient. For example, Stanford's policy on research "misconduct" applies "where a Stanford appointment or official affiliation is claimed, cited or implied in connection with the research." 60 But the most common concerns with quasi-third-party opinions involve secrecy, and university secrecy norms typically apply to conduct within the university, not to outside work. Stanford's presumptive prohibition against secrecy applies to research "conducted at Stanford."

Nevertheless, the concerns of anti-secrecy norms are pertinent to quasithird-party opinion practice, whether or not we deem this practice to occur "at" the university. Third-party opinion practice often gives individuals with private stakes in the issues significant control over the expression and disclosure of the academic's views. Moreover, these views and the work on which they are based significantly implicate the academic's institution. The implication arises because the client, in disseminating the views, invariably invokes the expert's university affiliation and because the third-party effect of the views depends, often heavily, on the university's reputation for impartiality and reliability.

For an illustration of the problem, consider Geoffrey Hazard's role in the Kaye Scholer affair. ${ }^{62}$ In 1992, the Office of Thrift Supervision (OTS) brought

58. E.g., Yale Univ., Yale University Faculty Handbook ch. X, f (B)(1)(a) (2002), available at http://www.yale.edu/provost/handbook/yfhtoc.html (mandating that faculty adhere to the "highest standards of ethical conduct, truth, and accuracy"); id. ch. X, I (B)(1)(b) (forbidding "secret or classified research" because it is inconsistent with goals of "open publication, free discussion, or access to research").

59. See DereK BoK, Universities IN THE MaRKeTPlaCE: The Commercialization of Higher EduCATION 64-66, 143-44 (2003); DEBORAH L. RHOde, In PURSUIT OF KNOWLEdGe: SCHOLARS, STATUS, AND ACADEMIC CULTURE 59-61 (2006); see also YALE UNIV., supra note 58 , ch. $X$, If $(B)(1)(c)$ ("[Researchers must] be able to publish the results of their research without prior approval of a sponsor.").

60. Stanford Univ., Research Policy HandBook: Research Misconduct: Policy ON ALLEGATIONS, INVESTIGATIONS AND REPORTING $\S 1(\mathrm{~A})(3)$ (2006), available at http://www.stanford.edu/dept/DoR/rph/2-5.html.

61. Stanford Univ., Research Policy Handbook: OpenNess IN Research, $\S 1$ (2007), available at http://www.stanford.edu/dept/DoR/rph.

62. My discussion of the Kaye Scholer case and Hazard's opinion draws on William $H$. Simon, The Kaye Scholer Affair: The Lawyer's Duty of Candor and the Bar's Temptations of 
charges of unprofessional conduct against the Kaye Scholer law firm in connection with its representation of Lincoln Savings \& Loan, which had undergone one of the more spectacular failures in the Savings \& Loan crisis. The charges were never officially resolved on the merits; Kaye Scholer settled the case without conceding wrongdoing. Much of the organized bar rallied around Kaye Scholer, and while sympathy has been expressed for the charges by academics and journalists, the dominant impression among practitioners is probably that they were unfair.

After the charges were announced, Kaye Scholer launched a public relations campaign in which an early move was the release of a twenty-twopage statement purporting to summarize the opinion of "Professor Geoffrey C. Hazard, Jr., of the Yale Law School, the nation's foremost authority on legal ethics." The opinion was drafted to convey a general endorsement of Kaye Scholer's conduct without acknowledging or engaging the specifics of any of the OTS charges. In particular, the opinion adopted the central line of Kaye Scholer's campaign, which was to mischaracterize the OTS charges as based on claims of failure to disclose information about client wrongdoing. Thus, the statement repeatedly asserted anodyne propositions such as "Kaye Scholer did not have a duty to disclose weaknesses in Lincoln's position." ${ }^{.63}$ In fact, not one of the many charges was based on failure to disclose; all the charges concerning deceit alleged active participation by the firm in the client's misconduct. The statement concluded that "in the conduct described above, Kaye Scholer did not violate existing standards of ethical conduct." 64 Yet, virtually none of the conduct OTS alleged had been "described above." 65

Hazard's opinion has been widely cited by Kaye Scholer's many defenders. ${ }^{66}$ Yet, Hazard has indicated repeatedly but vaguely that the opinion may not represent his views. ${ }^{67}$ When I suggested that Hazard had a duty as an academic to clarify his views and respond to criticisms, or at least to correct the client's mischaracterizations of his views, he denied that he had any such duty,

Evasion and Apology, 23 LAW \& SOC. INQUTRY 243, 247-61 (1998).

63. Practising Law Inst,, The attorney-Client Relationship after Kaye SCHOLER 397 (1992).

64. Id. at 398.

65. Id.

66. E.g., Marvin E. Frankel, Lawyers Can't Be Stool Pigeons, N.Y. TiMES, Mar. 14, 1992 , at A22.

67. When The American Lawyer criticized his opinion, Hazard vaguely distanced himself from it, noting that it was "kind of preliminary." Susan Beck \& Michael Orey, They Got What They Deserved, AM. LAW., May 1992, at 68, 75. Hazard coauthored a textbook which conceded that the OTS charges were "at least as strong" as those a federal court held sufficient to withstand summary judgment in a case against another firm that represented Lincoln. GEOFFrey C. HAZARD ET AL., THE LAW AND ETHICS OF LAWYERING $793 \mathrm{n} .91$ (2d ed. 1994). In his reply to my 1998 criticism, he indicated that he was not aware what the precise factual allegations or charges were at the time Kaye Scholer drafted its report of his opinion. Geoffrey Hazard, The Duty or Option of Silence, 23 LAW \& SOC. INQUIRY 339, 339 (1998) [hereinafter Hazard, Duty or Option]. 
offering as explanation only that there was "no authority" saying that he did. ${ }^{68}$

It bewilders me how Yale University or the University of Pennsylvania (where Hazard subsequently moved) could find such activity consistent with its dignity and responsibility. Universities do not vouch for the validity of the views their faculty members express, but they should oblige them to respect basic guidelines, including one that insists that an academic must actually believe the views she endorses. In effect, Hazard rented the university's imprimatur to Kaye Scholer for his own profit, allowing the firm to make virtually unconditional use of it. The use the firm made of the university's reputation-to give an aura of soundness and impartiality to its own selfinterested conclusion-was inconsistent with the principles on which that reputation is based.

Academic institutions, and law schools in particular, should elaborate their principles of candor and openness to apply to quasi-third-party opinion practice. To start things off, I propose a basic norm. The institutions should announce it as an aspiration to which all members are expected to adhere. It could be enforced through criticism and shaming without any formal disciplinary process. It could also be enforced more formally and coercively, but I take no position on whether that would be a good idea. ${ }^{69}$

Here is the basic norm: When an academic publicly expresses a view as an expert or authorizes another to attribute an expert view to her, she should take care that the view be publicly accessible and clearly and accurately expressed, with its basis as fully stated as feasible. This duty includes an obligation to clarify and revise public descriptions of her view as long as the view is the subject of public attention. The academic should not make any private commitments incompatible with this principle. Exceptions may be made but only in compelling circumstances, and they should be publicly documented to the extent feasible.

The "as an expert" qualification is designed to exclude both amateur opinions not associated with the academic's field and views expressed as a partisan advocate, as long as academic authority is not invoked for them.

Under this norm, when the client goes public with the expert's opinion, the expert may not, without exceptional reasons, permit her to do so selectively, as Wolfram has permitted with his Vinson \& Elkins opinion, or to control the public characterization of her views, as Hazard has done with his Kaye Scholer opinion. She should make them as readily accessible as possible. If she has substantial quasi-third-party practice, she should maintain a website on which to post her opinions. It would be a challenging task to devise principles for

68. Hazard, Duty or Option, supra note 67, at 339.

69. My hesitation arises from awareness that important academic values sometimes produce oppressive over-regulation. Human subjects review boards are a notable example. See Philip Hamburger, The New Censorship: Institutional Review Boards, 2004 SUP. CT. REV. 271, 343-50. 
deciding when a client's desire for confidentiality is sufficiently compelling to warrant exceptions. For now, I merely note that it will often be possible to accommodate the client's need for confidentiality while making most of the expert's opinion accessible. Bar association ethics committees and sometimes disciplinary bodies, for example, have long experience of reporting opinions and decisions publicly in forms that conceal the identities of the parties involved in the underlying case while giving a detailed account of their factual bases.

In the litigation context, we can acknowledge two problems that will be encountered in implementing the principle, though neither ultimately presents a serious objection to it.

First, there is the problem of drawing the line between first-party and quasi-third-party legal advice. In the ex ante situation, where the client has not yet acted, the client often consults the lawyer for advice about how she should proceed; then when the client decides on a course of action, she may want to rely on the lawyer's advice for support in the event the conduct is later challenged. In the ex post situation, the client is looking for exoneration. She consults the lawyer to find out what the lawyer's view would be, and plans to use the view only if it is supportive. In either of these situations, it seems appropriate for the lawyer to consider her role as a first-party legal advisor, subject to normal confidentiality obligations, up to the point at which it becomes highly probable that the client will rely publicly on the advice. At that point, confidentiality with respect to all matters on which the advice is based is no longer appropriate. ${ }^{70}$

The expert should not, without good reason, postpone disclosure to accommodate the client's strategic interests. Sometimes the client may be content with prompt disclosure because it will strengthen its claim of good faith in the event that its conduct is challenged. Often the client will not be happy about early disclosure. The expert will then have to evaluate the legitimacy of the client's reasons. A desire to minimize the chances of public discovery or scrutiny should not be a sufficient reason unless the client has a plausible claim of privacy with respect to the matter. Regulators may be able to pass rules tailored to specific fields. For example, it would not be a radical step for the IRS to add to its current regime a requirement that opinions can be used for penalty protection only if they have been made accessible to the IRS no later

70. In the course of litigation, the client's reliance on advice of counsel as a defense usually constitutes a waiver of attorney-client privilege by "putting in issue" the otherwise confidential communications, In re Echostar Commc'ns Corp., 448 F.3d 1294, 1299 (Fed. Cir. 2006), and the decision to call an expert as a witness at trial opens his opinions to broad discovery. 2 JACK WEINSTEIN ET AL., WEINSTEIN'S EVIDENCE If 503(a)[3][01] nn.17-18, at 503-36 (1996). My transparency proposal generalizes the principle reflected in these cases that, when an expert seeks to influence a public controversy with an opinion, both the opinion and its bases should be open to public scrutiny. 
than the filing of the relevant return. ${ }^{71}$

Second, the proposal is in strong tension with the conception of the expert witness's role that prevails among litigators. ${ }^{72}$ This conception virtually erases the distinction between expert and advocate. It applies to witnesses the confidentiality and conflict-of-interest norms the bar prescribes for partisan lawyers. It instructs the witness to develop her opinions in private, consulting only the party who retained her and the party's partisan advisors. And it tells her to avoid making records of her preliminary thoughts. It forbids outside consultation and casual writing in order to prevent disclosures that might reduce strategically advantageous surprise at trial or create opportunities for impeachment with what turn out to be prior inconsistent statements.

There are two problems with the litigators' view. First, it is inconsistent with the premise on which the expert is presented to the court, which is that the expert is disinterested and testifying to what she genuinely believes to be the best answer to the question. Second, where the expert is an academic or relies on academic credentials, it is inconsistent with the premises of the academy as to how sound understanding is achieved. These premises prescribe openness and the continuous exchange of views among different perspectives. They treat willingness to reconsider one's views as a sign of self-confidence and integrity, rather than as the litigators' view it, of weakness or duplicity.

No wonder that many experts are confused about their roles. They know they are supposed to be independent to some degree, but they have trouble defining that degree, and they get little help from the litigators. The economic pressures that arise from the fact that the client is paying are reinforced in circumstances where the expert can discuss her opinions and her role only with partisans.

Tension with the litigation culture is inevitable in any effort to vindicate academic values with respect to quasi-third-party advice. But academic standards could make a difference for the better. Even without direct formal enforcement, they might generate pressures through shaming within the academy. And courts could treat their violation as appropriate impeachment in court.

\section{A CASE STUdy: EThics EXPERTS AND Defendant PAyMENTS To PLAINTIFFS' LAWYERS IN AGGREGATE LITIGATION}

A recent case involving settlement of aggregate litigation offers further illustration of the problems of quasi-third-party academic advice. The settlement was negotiated in 2000 by the New York firm of Leeds, Morelli \&

71. Current rules require or condition benefits on the disclosure of certain transactions but generally do not require advance disclosure of opinions. See supra note 16 and accompanying text.

72. This conception is noted and criticized in Gross, supra note 10, at 1148-52. 
Brown (LM\&B) on behalf of hundreds of employment discrimination plaintiffs with the cell phone company Nextel. (Nextel has since been merged into Sprint.) Former clients have sued LM\&B for malpractice and other misconduct in connection with the case. Other lawsuits by former clients have alleged similar conduct by the firm in group representations against four other employers. ${ }^{73}$

The Nextel case is important both for what it shows about plaintiffs' lawyer responsibility in aggregate litigation and what it shows about the market for quasi-third-party opinions. The dispersion of individual claimants in aggregate litigation and their relatively small stakes raises concerns about the efficacy of traditional mechanisms of lawyer-client accountability. With the class action, this concern has led to distinctive supervisory procedures that often create roles for experts. Notably, procedural rules require judicial certification of the adequacy of class representation and the fairness of settlements, and counsel often bring in experts to reassure the court on such matters. ${ }^{74}$ Our case involved, not a class action, but informally aggregated individual claims. This procedure eluded the judicial scrutiny required for class actions. Nevertheless, the lawyers involved, recognizing the possibility of later challenge, called on academic experts for ex ante legitimation, and when challenge emerged, retained further ex post expertise. The academics responded in a manner that left unabated, and perhaps exacerbated, the accountability problems inherent in the situation.

My views on this transaction are hotly disputed, but an important purpose of my argument does not depend on whether I am right about the merits. That purpose is to show that academic expertise can be quite influential in highstakes situations and that the form it takes and the circumstances under which it is delivered are often not conducive to reliability. The expert advice given in this case, especially a centrally influential ex ante opinion by Geoffrey Hazard, involved striking departures from the norms of analytical support and reasonable framing discussed above. Moreover, the advice was given under conditions of strong secrecy and thus (until now) largely immune from public and peer scrutiny. ${ }^{75}$

73. Vaughn v. Leeds, Morelli \& Brown, P.C., No. 04 Civ. 8391, 2005 WL 1949468 (S.D.N.Y. Aug. 12, 2005) (Prudential Securities Inc.); Ficklin v. Penguin Group (USA), Inc., No. L-3765-03, 2007 WL 560983 (Super. Ct. of N.J., App. Div. Feb. 26, 2007); Complaint, Ganci v. Prudential Ins. Co., Civ. No. L-1806-05 (N.J. Super. Ct., Bergen Co. Mar. 20, 2007); Complaint, Lee v. Leeds, Morelli \& Brown, No. $8651 / 05$ (N.Y. Supreme Ct., Kings County Mar. 22, 2005) (Bear Stearns).

74. FED. R. CIV. P. 23(a), (e). A notable illustration of the role of experts can be found in the district court opinion in Georgine v. Amchem Products, Inc., 157 F.R.D. 246, 296-99, 302-03, 306-10 (E.D. Pa. 1994) (discussing the expert testimony of Professors Geoffrey Hazard, Susan Koniak, Roger Cramton, John Coffee, and John Freeman), vacated, 83 F.3d 610 (3d Cir. 1996), aff'd sub nom. Amchem Prods., Inc. v. Windsor, 521 U.S. 591 (1997).

75. I learned about the Nextel settlement as a consultant to plaintiffs' counsel in some of the cases arising from settlements negotiated by LM\&B. 


\section{A. Factual Background}

Although there is much disagreement between LM\&B and many of their former clients, the facts that concern us are undisputed, with some exceptions that I indicate below.

\section{1. $L M \& B$ and its 587 clients}

\section{Sometime prior to the beginning of $2000, \mathrm{LM} \& B$ signed up as clients}

There have been three lawsuits against LM\&B by former clients in the Nextel matter. A class action in Colorado state court on behalf of all the original claimants except about forty opt-outs was settled. Complaint, Foster v. Leeds Morelli \& Brown, No. 02-CV-1484 (Colo. Dist. Ct., County of Arapahoe (2002). (Several of the Nextel claimants were from Colorado, and LM\&B opened an office in Colorado in the course of the case.) The record of this case has been sealed, and no one is allowed to discuss the terms of the settlement.

A second Colorado case was filed on behalf of two of the original clients who opted out of the class action. Complaint, McNeil v. Leeds, Morelli \& Brown, P.C., No. 03-CV-893 (Colo. Dist. Ct., Denver County Oct. 6, 2003). I refer to this case below as "the Denver case." The two claimants in the Denver case were distinctively situated because they had been employed by LM\&B to assist in communicating with other clients and (they say, though the firm disputes it) soliciting new clients. A jury verdict in favor of the defendants was returned after a trial in November 2007.

The third case is a class action originally filed in New Jersey state court, but after removal to federal court and interdistrict transfer, it is now pending in the Southern District of New York. Complaint, Johnson v. Nextel Commc'ns Inc., No. 1:07-cv-08473 (S.D.N.Y. Oct. 23, 2006). It seeks to represent the remaining opt-out claimants against LM\&B and to assert claims against Nextel on behalf of all the original clients. I refer to this case below as "the federal case."

I had no involvement in the Colorado class action. I have consulted informally with plaintiffs' counsel in the federal case. I agreed to testify as an expert for the plaintiffs in the Denver case but ultimately did not do so. (The court granted a defense motion to exclude me on the ground that pretrial disclosure of my testimony had been inadequate. Plaintiffs' counsel has stated that he had decided not to call me.)

Because the Colorado class action is sealed and there has been little discovery in the federal case, the litigation opinions and much of the evidence I refer to come from the Denver case. The circumstances of the two plaintiffs in that case were in some respects unusual, but the opinions and evidence to which I refer apply to the general experience of the great majority of claimants.

A few readers have expressed qualms about my carrying into the realm of scholarship a debate I was invited to join as a litigation expert. My view is that this practice is not only permissible (where not inconsistent with confidentiality commitments), but desirable. In effect, I am treating my expert role as an extension of my academic one. And so I should. The idea that the two roles are continuous is implied when the consulting expert's academic credentials are invoked as a token of reliability. In reporting my views, I am subjecting them to the test of peer scrutiny that the academy regards as critical to reliability. Continuity is also implied in the frequent argument by academics that consulting benefits their academic work by putting them in touch with practice. A large part of this benefit would be sacrificed if they felt categorically barred from making the most effective use of their experience.

Finally, without suggesting that such refusal is either a necessary or a sufficient condition of scholarly detachment, I report that I declined to take a fee for my work on the matter. 
hundreds of people with employment discrimination claims against Nextel. In the retainers I have seen, the firm undertook to represent the client in a "labor action" and to contact Nextel "to seek a negotiated settlement and, if necessary, the filing of a lawsuit regarding your claims." recovery be divided one-third to the firm and two-thirds to the client. ${ }^{77}$

The firm filed more than 200 EEOC complaints against Nextel and made various public pronouncements accusing the company of discriminatory practices. ${ }^{78}$ Nextel responded in a June 2000 press release that LM\&B had refused to discuss all but a few of the claims until Nextel "capitulat[ed] to exorbitant fee demands." 79

Negotiations resumed, and in September 2000, LM\&B and Nextel executed a "Dispute Resolution and Settlement Agreement" (DRSA). By this time, LM\&B represented 587 people with discrimination claims against Nextel. ${ }^{80}$ LM\&B purported to sign the agreement "on behalf of itself and the Claimants." 81 The agreement is twenty-nine double-spaced pages with about twenty pages of attachments. Exhibit A to the DRSA is a three-page "Individual Agreement" form intended for use by the claimants to assent to or ratify the DRSA.

\section{The aggregate settlement agreement (DRSA)}

The agreement is not lucidly written and requires careful reading, but the basic terms are undisputed.

a. LM\&B agrees to deliver client agreements and to process claims speedily

The claimants waive their rights to pursue their claims in any judicial or

76. Retainer Agreement, Signed by Denise McNeil (undated) [hereinafter Retainer 1] (authorizing representation by Leeds \& Morelli in claims against Nextel); Retainer Agreement, Signed by Alencia Ashton-Moore (undated) [hereinafter Retainer II] (same). Copies of all documents pertaining to LM\&B and the Nextel case are on file with the author.

77. Retainer I, supra note 76; Retainer II, supra note 76.

78. Defendants Leeds, Morelli \& Brown, P.C., Lenard Leeds, Steven Morelli, Jeffrey Brown, James Vagnini, and Bryan Mazzola's Supplemental Summary of Expert Opinions Served Pursuant to C.R.C.P. 26(a)(4), at 3, 12, 19, McNeil v. Leeds Morelli \& Brown, P.C., No. 03-CV-893 (Colo. Dist. Ct., Denver County Nov. 28, 2005) [hereinafter LM\&B Supplemental Disclosure]; Deposition of Steven A. Morelli Esq. at 61, McNeil v. Leeds, Morelli \& Brown, P.C., No. 03-CV-893 (Colo. Dist. Ct., Denver County Sept. 18, 2006).

79. Press Release, Nextel Communications, Inc. (June 20, 2000), available at http://phx.corporate-ir.net/phoenix.zhtml?c=63347\&p=irol-newsArticle\&ID=99828\& highlight $=$.

80. Letter from Gregory I. Rasin to Jeffrey K. Brown, Esq. 1 (Aug. 29, 2001) (on file with author).

81. Dispute Resolution and Settlement Agreement 29 (Sept. 28, 2000) (on file with author) [hereinafter DRSA]. 
administrative forum, and specifically to bring a class action, waive rights to punitive or injunctive relief, and agree to resolve the claims in a specified alternative dispute resolution (ADR) process. ${ }^{82}$ The process begins with an exchange of information by each claimant and the company and then proceeds, if necessary, through negotiation, mediation, and binding arbitration. ${ }^{83}$ Nextel agrees to pay the "administrative fees" of the process (specifically excluding the costs of expert advisors or witnesses for the claimant). ${ }^{84}$

To begin the process, LM\&B agrees "[a]s promptly as possible" to deliver to Nextel signed "Individual Agreements" from its 587 clients confirming their acceptance of the ADR procedure, along with statements regarding their claims. ${ }^{85}$ The firm also agrees to deliver within two weeks requests or stipulations for dismissal of all administrative complaints filed by any of the claimants. ${ }^{86}$

LM\&B acknowledges its understanding that, for Nextel, "time is of the essence" with respect to the various deadlines set out in the agreement. ${ }^{87}$

\section{b. Nextel agrees to pay LM\&B $\$ 7.5$ million}

Nextel promises two forms of payment to LM\&B. The payments total $\$ 7.5$ million, although the total does not appear in the agreement.

First, attorneys' fees and expenses: Nextel agrees to pay $\$ 5.5$ million to LM\&B for attorneys' fees and otherwise unreimbursed expenses of representing the claimants in the ADR process. ${ }^{88}$ The firm gets $\$ 2$ million within three business days after it has delivered to Nextel signed and notarized "individual agreements" from "each claimant." 89 It then becomes entitled to $\$ 1.5$ million more when half of the claims have proceeded to resolution in the process, and the remaining $\$ 2$ million when all the claims have been resolved. ${ }^{90}$ LM\&B agrees that all claims will be resolved within 45 weeks of the "effective date" of the DRSA (basically, the date of the delivery of the individual agreements). ${ }^{91}$ Nextel may deduct $\$ 50,000$ from the final payment due LM\&B for each month after this deadline that any claims have not been resolved or submitted to binding arbitration (with certain minor exceptions) ${ }^{92}$

Second, the "consultancy": On conclusion of the ADR process, Nextel

82. Id. ๆ $5,7(\mathrm{a}), 7(\mathrm{e})$; id. Exhibit A $\ 2$ (individual agreement).

83. Id. $\lceil 7$.

84. $I d . \rrbracket 7(\mathrm{~g})$.

85. Id. ๆ 6(a).

86. Id. ๆ 5 .

87. Id. I 1(c).

88. Id. ๆ 11(a).

89. Id. $\{\uparrow 11(\mathrm{a}), 14$.

90. Id. ๆ11(a).

91. Id. I11(b).

92. Id. 
agrees to retain LM\&B as a "legal consultant . . . with only such duties and responsibilities as may be assigned to it by Nextel and which may include assistance and legal advice with regard to the Companies' anti-discrimination and diversity policies and programs." 93 Nextel is to pay LM\&B $\$ 83,333.34$ per month for twenty-four months (a total of $\$ 2$ million, though that figure does not appear in the document). ${ }^{94}$

\section{c. LM\&B agrees to refuse to represent or refer other claimants}

LM\&B asserts that it does not intend to represent any new clients with claims against Nextel. ${ }^{95}$ This commitment is explained as a consequence of LM\&B's belief that "it is in the best interest of its clients that it devote its resources" to the current claims. ${ }^{96}$ LM\&B also agrees not to refer anyone with claims against Nextel to other lawyers (or to accept any fees for such referrals) ${ }^{97}$ This commitment is explained as a consequence of LM\&B's belief that "it is in the best interest of LM\&B's clients for the Companies not to also be distracted" by other claims. ${ }^{98}$

\section{d. Clients are forbidden to discuss claims with each other or anyone else except professional advisors}

The DRSA and the individual agreements provided that each claimant will not disclose anything about the DRSA or her claim against Nextel to "any person" except the claimant's "personal attorney or financial advisor, or expert retained" for the purposes of the ADR process. ${ }^{99}$ In the event a claimant makes a prohibited disclosure, he or she forfeits her right to compensation (and must return any compensation received) and remains bound by her waiver of judicial and administrative recourse. ${ }^{100}$

\section{e. Clients are obliged to stay with $L M \& B$, and $L M \& B$ is prohibited from associating outside counsel}

The agreement provided that "[e]ach claimant agrees that LM\&B shall be his/her legal representative throughout DRP ...."101 It also provided that LM\&B may not retain any lawyer not associated with the firm to represent or

93. Id. \I 12.

94. Id.

95. Id. ๆ1(c).

96. Id.

97. Id. ๆ 2(c).

98. Id.

99. Id. ๆ 4(a).

100. Id. \4(c); id. Exhibit A, ๆ 1; id. Exhibit D, ๆ 2.

101. Id. ๆ 7(a); id. Exhibit $\mathrm{A}$, ๆ 1 . 
assist in representing any claimant. ${ }^{102}$

\section{The individual agreements and the ADR process}

\section{a. Most clients agree after consultation with LM\&B}

By February 7, 2001, all but fourteen of the 587 claimants had signed "individual agreement forms" accepting the DRSA. LM\&B and Nextel negotiated an amendment to the DRSA reducing LM\&B's fees slightly to reflect the fourteen non-consenting claimants. ${ }^{103}$

In advising the claimants about the DRSA, LM\&B invited them to examine copies of the DRSA but except for a small number of "representatives," did not permit them to retain copies. The lawyers prepared two documents for distribution to clients- the three-page "Individual Agreement"104 and another five-page document entitled "Highlights of the Settlement Agreement with Nextel." 105 Neither of these documents mentioned the amounts or conditions of the payments Nextel was to make to LM\&B. Both referred to the fact that Nextel had agreed to pay attorneys' fees but did not mention any conflict of interest in connection with this provision. (One of these documents refers to the fees as sums "that claimants might otherwise have to pay"; the other refers to Nextel's promise to pay as "consideration" for the claimants' agreement to accept ADR.) ${ }^{106}$ Both documents mention that Nextel planned to retain LM\&B after the conclusion of the ADR process and asked the claimants to consent to the "conflict of interest" that such retention involved, but neither said anything about the nature and effects of the conflict. ${ }^{107}$

Beyond these facts, there is dispute. The lawyers say that they disclosed the amounts of the payments orally to the claimants and that they went over the DRSA "line by line" orally with each claimant, though it is not clear whether they claim to have done anything more than describe the literal terms of the document. ${ }^{108}$ Some of their former clients, however, have asserted they were not told of the amounts and conditions of the payments, that they thought that

102. Id. ๆ $11(\mathrm{a})$.

103. Dispute Resolution and Settlement Agreement amend. No. 2 (Feb. 7-8, 2001) (on file with author).

104. DRSA, supra note 81, Exhibit A.

105. Deposition of James Vagnini Esq. at 53, McNeil v. Leeds, Morelli \& Brown, P.C., No. 03-CV-893 (Colo. Dist. Ct., Denver County Sept. 20, 2006); Highlights of the Settlement Agreement with Nextel (undated) (on file with author).

106. Highlights of the Settlement Agreement with Nextel, supra note 105, ๆ 29.

107. Id. \30.

108. Deposition of James Vagnini Esq. at 53-61, McNeil v. Leeds, Morelli \& Brown, P.C., No. 03-CV-893 (Colo. Dist. Ct., Denver County Sept. 20, 2006) [hereinafter Vagnini Deposition]; Deposition of Steven A. Morelli Esq. at 38-39, McNeil v. Leeds, Morelli \& Brown, P.C., No. 03-CV-893 (Colo. Dist. Ct., Denver County Sept. 18, 2006) [hereinafter Morelli Deposition]. 
the attorneys' fee that Nextel agreed to pay was the one-third contingency provided in their retainers, or that they were told that the purpose of the consultancy was to make sure that LM\&B could continue to protect them against discrimination by Nextel after the ADR process was over. ${ }^{109}$

\section{b. Claims are "resolved"}

Apparently, LM\&B was able eventually to bring its clients' claims to sufficient resolution to receive the final attorneys' fee payment under the DRSA and to undertake the "consultancy." LM\&B and Nextel have refused to describe the nature of the work that LM\&B has performed.

\section{c. Aftermath}

Some of LM\&B's former clients have sued them, complaining, inter alia, that they did not agree to the payment provisions and that they were induced by LM\&B to waive rights and settle claims against Nextel for less than their value.

\section{B. The Ethics Experts}

Nextel asked Geoffrey Hazard for his opinion on the DRSA before it and LM\&B signed the agreement. Hazard gave a four-page written opinion, which is reprinted here as Appendix II. Nextel showed it to LM\&B. ${ }^{110}$

Hazard refers to the DRSA in very general terms. He mentions the provision for Nextel to pay attorneys' fees and expenses but does not refer to the amounts of the fees or their conditions. He refers to the fees and expenses as sums "the Claimants would otherwise be obligated to pay" LM\&B. ${ }^{111} \mathrm{He}$ also mentions the "consultancy," but again, there is no mention of its conditions or the amount of compensation. Hazard notes that the "engagement can benefit present and future Nextel employees . . . by providing objective and experienced guidance in the company's handling of employee relations." 112

Hazard then goes on to express the following opinions:

-There is no violation of the prohibition on restrictions of practice.

109. Complaint ๆ $28-57$, Johnson v. Nextel Commc'ns, Inc., No. 1:07-cv-08473 (S.D.N.Y. Oct. 23, 2006); Deposition of Denise L. McNeil at 92-95, McNeil v. Leeds, Morelli \& Brown, P.C., No. 03-CV-893 (Colo. Dist. Ct., Denver County July 6, 2006); Deposition of Alencia V. Ashton-Moore at 72-83, 120-21, 251-55, McNeil v. Leeds, Morelli \& Brown, P.C., No. 03-CV-893 (Colo. Dist. Ct., Denver County Nov. 16, 2005).

110. LM\&B Supplemental Disclosure, supra note 78, at 28; Deposition of Roy Simon at 18, McNeil v. Leeds, Morelli \& Brown, P.C., No. 03-CV-893 (Colo. Dist. Ct., Denver County Oct. 19, 2006).

111. Letter from Geoffrey C. Hazard, Jr., to Mary Elizabeth McGarry, Esq. (Sept. 28, 2000), reprinted infra app. II.

112. Id. at 149 . 
Professional responsibility rules generally forbid lawyers to propose or enter "an agreement in which a restriction on the lawyer's right to practice is part of the settlement of a client controversy." 113 Hazard opines that the provision in the DRSA precluding LM\&B from representing or referring other claimants does not violate this rule. As explanation, he says that "representation of the Claimants under the Agreement could well constitute a conflict of interest with other potential clients" and that DRSA contemplates "continuing cooperative procedures between Leeds Morelli and Nextel that could be jeopardized" by new claims. ${ }^{114}$

- Conflicts can be cured by informed consent. Professional responsibility rules preclude a lawyer from proceeding when a representation may be "materially limited" by the lawyer's own interests unless two conditions are satisfied. ${ }^{115}$ The first condition is that the lawyer (in the language effective in 2000) "reasonably believe[] the relationship will not be adversely affected" by the conflict. ${ }^{116}$ When this condition is satisfied, the conflict is said to be "consentable." The remaining condition is informed consent, or as the rule put it at the time of Hazard's opinion, "consent[] after consultation.".117

Hazard opines without explanation that the conflict presented by the payment provisions is "consentable." $118 \mathrm{He}$ further states that "informed consents should be obtained" but does not discuss what informed consent would involve other than to say it must be "adequate" and to note, "[i]t is not obligatory that the consents of the claimants ... be in writing, except in a few jurisdictions such as California." He states further, "I assume that LM\&B will provide such a disclosure." 119

-The commitment of clients to stay with $L M \& B$ is not legally enforceable. A basic principle of professional responsibility holds that the client is always free to discharge the lawyer. ${ }^{120}$ Responding to the DRSA provision that commits the clients to stay with LM\&B, Hazard says, "The Claimants can make such a commitment on a moral basis but it is not legally binding."121

113. Model Rules of Prof'l CONDUCt R. 5.6(b) (2002).

114. Letter from Hazard, supra note 111.

115. MOdel RULES OF PROF'L CONDUCT R. 1.7(a)(2) (2002).

116. Id. R. 1.7(b)(1) (2000).

117. MODEL RULES OF PROF'L CONDUCT R. 1.7(b)(4) (2002) ("informed consent"); MODEL RULES OF PROF'L CONDUCT R. 1.7(b)(2) (2002) ("consent[] after consultation").

Hazard also opines that the payment provision does not violate Model Rule 1.8(f) which says that a lawyer may not accept payment from someone other than the client unless "the client gives informed consent" and there is "no interference with the lawyer's independence of professional judgment." MODEL RULES OF PROF'L CONDUCT R. 1.8(f) (2002); Hazard, supra note 111 . Since the issues presented by this rule are virtually the same as those presented by Rule 1.7(b), I do not discuss them separately.

118. Hazard, supra note 111.

119. Id.

120. RESTATEMENT (THIRD) OF THE LAW GOVERNING LAWYERS $\S 31 \mathrm{cmt}$. d. (2000).

121. Hazard, supra note 111. 
At about the same time that Nextel consulted Hazard, LM\&B consulted Roy Simon. Simon did not put his opinion in writing, but we know that he concluded, as Hazard did, that any conflict problems associated with the fee provision or the "consultancy" could be cured by informed consent. ${ }^{122}$

In a $2003 \mathrm{ABC}$ news story-the only major media coverage of the case to date-Nextel was reported as responding to allegations by former LM\&B clients that they had been "sold out" with the assertion that "the agreement had been reviewed and approved by a nationally-known ethics expert." 123

In connection with one of the lawsuits by former LM\&B clients, Nextel retained, in addition to Hazard, a practitioner professional responsibility expert, and LM\&B retained Roy Simon, Bruce Green, and a practitioner expert. In the lengthy written pretrial disclosure of the testimony of these experts in one of the pending cases, ${ }^{124}$ Hazard reaffirmed his opinion; ${ }^{125}$ the four other experts agreed with Hazard on most or all of the conclusions expressed in his letter, and none indicated disagreement with him on anything. ${ }^{26}$ In addition, Roy Simon, Green, and the practitioner experts, on the basis of some assumed version of the defendants' story, opined that LM\&B's disclosure to its clients was adequate for informed consent. ${ }^{127}$ And they concluded that $\$ 5.5$ million was a reasonable fee for the work that $L M \& B$ engaged to perform. ${ }^{128}$

A notable feature of the ex post litigation opinions is the way they build on the authority of Hazard's and Roy Simon's ex ante opinions. Three experts state that it was "appropriate" for Nextel and LM\&B to seek ethics advice prior to entering into the DRSA. ${ }^{129}$ (No one disputes that point, but clearly the

122. Deposition of Roy Simon, supra note 110, at 11-22.

123. News Story by Sarah Wallace (WABC-TV television broadcast Nov. 4, 2003) (on file with author).

124. References to the experts' pretrial opinions are to the following documents in the Denver case: (1) Defendant Nextel Commc'ns, Inc.'s Supplemental C.R.C.P. 26(a)(2)(B)(I) and (II) Expert Witness Disclosures, McNeil v. Leeds Morelli \& Brown, P.C., No. 03-CV893 (Colo. Dist. Ct., Denver County Apr. 16, 2007) [hereinafter Nextel Disclosure]; (2) Defendants Leeds, Morelli \& Brown, P.C., Lenard Leeds, Steven Morelli, Jeffrey Brown, James Vagnini and Bryan Mazzola's Second Supplemental Summary of Expert Opinions Served Pursuant to C.R.C.P. 26(a)(4), McNeil v. Leeds Morelli \& Brown, P.C., No. 03-CV893 (Colo. Dist. Ct., Denver County Apr. 13, 2007) [hereinafter LM\&B Second Supplemental Disclosure]; (3) Defendants Leeds, Morelli \& Brown, P.C., Lenard Leeds, Steven Morelli, Jeffrey Brown, James Vagnini and Bryan Mazzola's Expert Endorsement Pursuant to C.R.C.P. 26(a)(2)(b), McNeil v. Leeds Morelli \& Brown, P.C., No. 03-CV-893 (Colo. Dist. Ct., Denver County Nov. 28, 2005) [hereinafter LM\&B Expert Endorsement]; and (4) LM\&B Supplemental Disclosure, supra note 78.

125. Nextel Disclosure, supra note 124 , at 7.

126. Id. at 4-6; LM\&B Expert Endorsement, supra note 124, at 3, 5-6; LM\&B Supplemental Disclosure, supra note 78, at 7-10, 23-29.

127. Nextel Disclosure, supra note 124, at 5; LM\&B Supplemental Disclosure, supra note 78 , at $8,17,25-26$.

128. Nextel Disclosure, supra note 124, at 4-5; LM\&B Supplemental Disclosure, supra note 78, at 9, 17, 26.

129. LM\&B Expert Endorsement, supra note 124, at 3, 5-7. 
defendants planned to remind the jury of these consultations as often as possible.) Some go further and suggest that the ex ante opinions have weight on substantive questions. Bruce Green opines that the fact that Nextel "retained Professor Hazard to review the DRSA as well [i.e., in addition to LM\&B's retention of Roy Simon] . . . was an additional basis for LM\&B to conclude the DRSA was appropriate and ethical." ${ }^{.130}$ LM\&B's practitioner expert goes even further, contending that "because Nextel retained Professor Hazard to review the DRSA ... it was reasonable for LM\&B to conclude the DRSA was appropriate and ethical."131

Nextel's practitioner expert gives Hazard's opinion as a reason why the prohibition on representation of other clients was permissible. ${ }^{132}$ Concluding that the consultancy agreement was not a prohibited restriction on practice, LM\&B's practitioner expert gives as the only basis for her opinion the fact that Hazard said it was not. ${ }^{133}$

\section{Critique}

It should be sufficient to raise doubts about both the practitioner and the academic practices involved in this case to point out some salient deficiencies in Hazard's written opinion and to make a few specific comments about Green's and Roy Simon's contributions. One reason to focus on Hazard is that his opinion has been most influential. Another is that it is a self-contained statement, intended and used as a basis for practical decision. By contrast, I know the other experts' views only from summaries of their anticipated trial testimony. Although these summaries are each considerably longer than Hazard's opinion, they are not exhaustive. ${ }^{134}$

130. LM\&B Supplemental Disclosure, supra note 78, at 16.

131. Id. at 23; see also id. at 28. Doctrine suggests that reliance on advice of another has at most limited bearing in determining whether a lawyer has fulfilled professional responsibilities. See People v. Katz, 58 P.3d 1176, 1187 (Colo. O.P.D.J. 2002) (rejecting advice-of-counsel as defense to bar disciplinary charges); Florida Bar v. St. Louis, 967 So. 2d 108, 118 (Fla. 2007) (same); MODEL RULES OF PROF'L CONDUCT R. 5.2(b) (2002) (noting that a "subordinate lawyer" does not violate rules if she acts in accordance with supervisor's "reasonable resolution" of an arguable professional duty).

132. Nextel Disclosure, supra note 124, at 6.

133. Hazard wrote:

Ms. Dubofsky will explain that Nextel retained Geoffrey Hazard to evaluate and opine upon the ethical implications of the consultancy arrangement with LM\&B, that Professor Hazard concluded that the arrangement was ethical, and that LM\&B reviewed his written opinion before entering the provisions. Ms. Dubofsky will opine that under these circumstances, the DRSA's consulting provision is ethical and appropriate, and within the standard of care for lawyers practicing in Colorado in 2000.

LM\&B Supplemental Disclosure, supra note 78 , at 28 . Hennessey also gives strong weight to Hazard's opinion in this issue. Nextel Disclosure, supra note 124, at 6.

134. Roy Simon and Green testified at the trial in the Denver case in November 2007 that resulted in a verdict for defendants. I have not seen any reports of their testimony. Hazard did not testify because the claims against Nextel had been dismissed prior to the trial. 


\section{Conflicts}

a. The elephant in the room

Hazard's opinion is patently wrong on nearly every issue it addresses, but its most remarkable feature-shared by the opinions of the four other experts -is its complete silence on the nature of the conflict created by the payment arrangements of the DRSA. The DRSA was extraordinary in two respects. First, the plaintiffs' lawyers concluded negotiation of compensation for themselves from their clients' adversary without even beginning to negotiate relief for their clients. ${ }^{135}$ Second, the compensation they negotiated did not depend on either the lawyers' efforts or their results.

One way to start thinking about the two requirements of the conflict of interest rule-consentability and consent-is to ask: if this conflict were consentable, what kind of disclosure would have to be made to the client? The most important section of any adequate disclosure of the DRSA would go something like this:

The DRSA provides for Nextel to make payments to us totaling $\$ 7.5$ million. In order to earn this money, we do not have to achieve any particular result for you. What we have to do to get paid is, first, to persuade you and the other claimants to accept the DRSA, and second, to get your claim and the others resolved in the ADR procedure in accordance with deadlines set down by Nextel. As long as we get the claims resolved in time, we get paid regardless of whether you get a large award or whether you default and get nothing (and under the procedure, you can default if, for example, you miss a meeting without an excuse).

We get our first $\$ 2$ million from Nextel when we deliver signed individual agreements from every one of you. The DRSA permits Nextel to deny us all payment if we fail to persuade any of you to accept the DRSA. ${ }^{136}$ So when we counsel you about whether to accept the DRSA, we will have a $\$ 7.5$ million stake in getting you to agree. Although we will do our best to exercise independent judgment in your interests, there is a risk that this financial

135. Courts that have considered the practice of simultaneously negotiating recovery and fees have accepted it only with discomfort and qualification. For example, a notable decision says that the "better practice" is to negotiate recovery before discussing fees and that simultaneously negotiated settlements should be subjected to "careful scrutiny." Cisek v. Nat'l Surface Cleaning, Inc., 954 F. Supp. 110, 111 (S.D.N.Y. 1997). That was a class action, and thus the court's approval was required for settlement. Our case-where the fees were negotiated before the recovery-involved informal aggregation of claims that were never filed in court, and hence there was no opportunity for any kind of public scrutiny.

136. As things turned out, Nextel agreed to accept LM\&B's tender of 576 consents in return for LM\&B's agreement to lower its fee to reflect the 11 hold outs. LM\&B Supplemental Disclosure, supra note 78 , at 77. LM\&B might have anticipated that Nextel would accept consents from less than all the claimants, but it could not have been sure of any such leniency - the concession required negotiation of an amendment to the DRSA - and it seems unlikely that failure with respect to more than a small fraction would have been excused. 
interest will affect our advice.

After the $\$ 2$ million we receive when everyone agrees to the DRSA, we get $\$ 1.5$ million when half of the claims have been resolved, and another $\$ 2$ million when all claims have been resolved. When all the claims have been resolved, Nextel is going to hire us to work for it for two years and pay us $\$ 2$ million more. We will be doing whatever work they assign us, and it will not necessarily be in your interest.

The DRSA provides that all claims should be resolved within forty-five weeks of the start of the process. If we fail to meet this deadline, Nextel can reduce payments to us, and it is possible it could decline to hire us and pay us the final $\$ 2$ million.

If you accept the DRSA, we will make our best efforts to pursue your claims zealously and to exercise independent judgment in advising you on whether to accept settlement offers and in preparing your case. However, since it requires less effort and expense for us to settle quickly than to prepare, negotiate, and try your case, and since every time we turn down a settlement offer, we increase the risk of missing the deadline and incurring a large financial loss, there is a risk that our advice and strategic decisions will be affected by our financial interests.

\section{b. Consentability}

All of the defense experts say the conflict was consentable, but none of them say a word about what standards they apply for this judgment. Their silence does not reflect the existence of standards too well known to require mention. In fact, there is little authority on when a conflict is consentable. However, there can be no doubt that some arrangements are not consentable (at least in all jurisdictions relevant to this case). This case seems an especially good candidate for non-consentability.

The most critical considerations are these:

The alignment between lawyer incentives and client interests is especially bad. All compensation arrangements involve conflicts between lawyer and client interests, but the divergence here is much worse than with the percentage contingency of the original deal.

Further, the arrangement is highly unusual. ${ }^{137}$ The customary use of an arrangement in a particular context suggests similarly situated clients have decided that it is a good thing. A noncustomary arrangement lacks this reassurance.

In addition, the benefits are hard to assess (or even perceive). What did the claimants get for giving up the one-third contingency and accepting the much worse incentives of the fixed fee? The disclosure documents implied that the

137. Flat-rate compensation is not unknown, but in the civil sphere it is usually found in situations involving either (1) routine transactions, such as uncontested divorces or consumer bankruptcies, or (2) situations where there is a long-term relation between sophisticated business clients and their lawyers. 
fee provision was a boon to the claimants because it relieved them of the obligation to pay the fee themselves out of their recoveries. ${ }^{138}$ However, under their original agreement, the claimants would have been compensated for this expense by the statutory fee award that successful discrimination plaintiffs receive. ${ }^{139}$ In any event, the assertion that the claimants benefited by being relieved of their fee obligation merely raises the question of why Nextel would not have been willing to pay fees based on a percentage of the recoveries. ${ }^{140}$ It's an even larger mystery what the claimants got for agreeing to accept the perverse incentives of the consultancy arrangement. The only possible answer is that they got Nextel's agreement to the ADR process, but the process seems at least as much in Nextel's interest as in the claimants'.

Finally, the clients were legally unsophisticated, and it thus seems appropriate to apply to them the paternalistic constraints that the rule clearly contemplates.

An adequate analysis of consentability should also take account of four other features of the agreement that exacerbated the risks created by the skewed incentives. First, the confidentiality provisions meant there would be no publicity about the results. A substantial motivation for lawyers is often the desire to enhance their reputations through reports of successful representation, and conversely, to avoid injury to reputation by reports of bad practice. This motivation could not operate here.

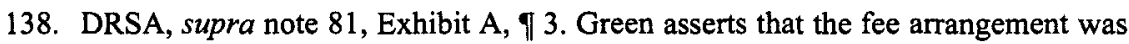
"a benefit to LM\&B's clients" for this reason. LM\&B Supplemental Disclosure, supra note 78 , at 17.

139. See, e.g., 42 U.S.C.A. $\S 2000 \mathrm{e}-5(\mathrm{k})$ (2007). Unless the agreement specifies otherwise, fee awards go entirely to the client, and the contingency fee percentage is applied only to the damage award. RESTATEMENT (THIRD) OF THE LAW GOVERNING LAWYERS $\$ \S 35$ cmt. d, 38(3)(b) \& cmt. f (2000). The agreements (retainers) with LM\&B that I (and presumably, Green and Roy Simon) have seen did not specify otherwise.

140. Roy Simon does make a response to this query, but it seems more a hypothetical debating point than a reasoned conclusion: "Professor Simon will explain to the jury the positive effect on an adversary such as Nextel in terms of a 'cap' on attorneys' fee exposure and how such an arrangement can result in higher settlements paid to claimants." LM\&B Supplemental Disclosure, supra note 78, at 8-9.

As opposed to the alternative of Nextel agreeing to pay the one-third attorneys' fee contingency of the original retainers, capping attorneys' fees but not damages eliminated the variance with respect to only a quarter of the expected value of Nextel's exposure. Even if Nextel was so risk averse that it valued this trivial reduction in risk-which seems highly unlikely in the case of a company sold for $\$ 35$ billion in 2005 -it is hard to see how it could have compensated the claimants for it. It did not agree to pay any minimum amount to the claimants in the DRSA, and once the DRSA was concluded, it had no incentive to offer any further concessions.

Roy Simon makes one more, equally implausible argument for claimant benefit: "Professor Simon will explain how [the flat rate] arrangement greatly benefits a client and allows the lawyer to focus on the merits of the client's claims rather than have concern over compensation for the lawyers themselves." LM\&B Supplemental Disclosure, supra note 78, at 8. All payment arrangements "allow" the lawyer to focus on the client's claims; the objection to the flat rate is that it minimizes his material interest in doing so. 
Second, the confidentiality provisions precluded the claimants from talking to each other. Thus, they could not compare results or talk about concerns they had about their lawyers. This removed for each client a major source of information that would otherwise have been available to assist in assessing the lawyers' performance.

Third, two unusual features of the agreement reduced the likelihood that a professional less beholden than LM\&B to Nextel would intervene on behalf of the claimants. The fee provision required LM\&B to bear the expense out of its own compensation of any expert witness for the claimant and thus created a strong disincentive to bringing one in. Another provision forbade LM\&B from bringing in any lawyers from outside the firm to work on the cases.

Fourth, resort to ADR precluded review of the results by a public official. Had the claims been asserted in a class action, a settlement would have been likely to require approval by a judge or public official. By inducing the claimants to waive their rights to class actions, the DSRA required them to give up this safeguard.

These four concerns would not have created insuperable conflict problems by themselves. However, they increased the clients' dependence on their lawyers' loyalty and capacity for independent judgment, just as the financial provisions of the DRSA were undermining that capacity.

In failing to explain its conclusion about consentability, Hazard's opinion violates the norm requiring analytical support.

\section{c. Consent after consultation}

I have already suggested the most important component of disclosure that would have been necessary. There are strong indications that such disclosure was not given. The written documents prepared for client disclosure do not mention the amount or conditions of the payments and contain no discussion of conflicts other than a conclusory reference with respect to the consultancy. Claimants in the actions against LM\&B alleged that such disclosure was never given. Unfortunately, the record is unclear as to what the lawyers claim to have said orally because both their testimony on this point and the characterizations of their exonerating experts describe the oral consultation only in conclusory terms, such as "line by line."141 Nevertheless, without getting into the factual disputes, we can make the following points about the experts' performance on this issue.

Hazard's letter simply assumes the issue away, noting that there must be informed consent, but saying nothing about what it should involve. Surely, this was not because Hazard thought the required disclosure obvious. Hazard knows that "in the process of obtaining informed consent, the lawyer or law firm must

141. Vagnini Deposition, supra note 108, at 53-54, 56; Morelli Deposition, supra note 108 , at 38 . 
do more than merely disclose the relevant facts; it must evaluate and analyze the conflict and advise the party on the wisdom of consenting." 142 Aside from the issue of consentability, the issue of required disclosure was the most difficult issue and the issue with the greatest practical stakes that was presented by Nextel's inquiry.

Yet, Hazard had only one thing to say about it: "It is not obligatory that the consents of the claimants represented by Leeds Morelli be in writing . . .."143 This was true, but, as the letter noted, irrelevant because the lawyers intended to get consent in writing. Hazard ignored the more important question of whether the disclosure necessary to effective consent should have been in writing. The rule does not require written disclosure invariably, but consultation with the client does require disclosure that is "reasonably sufficient to permit the client to appreciate the significance of the matter in question." 144 Where the material is as complicated as it is here, that standard would require written disclosure. ${ }^{145}$

Hazard violated the norm of reasonable framing by ignoring the key issues regarding consent, and by emphasizing the rule's flexibility on an irrelevant issue, he sent the wrong signal. He had seen documents suggesting a reluctance to come clean about the payment arrangements. (Recall that the DRSA never mentions the total payments and that the Individual Agreement form in the appendix contains no numbers at all or any explanation of payment conditions.) Telling the lawyers that the rule is flexible about whether consents have to be in writing was like telling a drunk getting into the driver's seat that he's allowed to turn right on a red light-true, but not the message he needs to hear.

For their part, Green and Roy Simon each concluded in the summaries of their anticipated testimony that some combination of the DRSA, the Individual Agreements, the "Highlights," and "in detail" oral disclosure were sufficient for informed consent. Neither acknowledged that both the documents the lawyers prepared for their clients omitted what were arguably the most important terms of the agreement (the amounts and conditions of payments) even though one of these documents purported to set out the agreement's "highlights." And neither mentioned any potential disadvantages of the agreement that should have been disclosed. ${ }^{146}$

142. Geoffrey C. Hazard, JR., W. William Hodes \& Peter R. Jarvis, 1 The Law of LAWYERING $§ 10.8$, at 10-23 (3d ed. Supp. 2004).

143. Hazard, supra note 111.

144. MOdel Rules OF PROF'L Conduct, Terminology (1999) (defining "consultation"). The current version defines the required "informed consent" to include "explanation about the material risks of and reasonably available alternatives to the proposed course of conduct." MODEL RULES OF PROF'L CONDUCT R. 1.0 (2002).

145. Model Rule 1.5(b) - not mentioned by Hazard - provides that "the basis or rate of the fee" should be communicated to a new client "preferably in writing." MODEL RULES OF PROF'L CONDUCT R. 1.5(b) (2002).

146. LM\&B Supplemental Disclosure, supra note 78, at 4-5, 15, 17. 


\section{Other issues}

Not all of the following issues are practically important in the case at hand, but I include them as further illustrations of the effects of market and adversarial pressures on putatively neutral judgment. With respect to each issue, Hazard failed either to provide analytical support or to frame reasonably.

\section{a. Reasonableness of the fee}

Hazard ignored the issues presented by the DRSA of compliance with the rule that stipulates that "[a] lawyer shall not make an agreement for, charge, or collect an unreasonable fee" and that the basis of the fee shall be disclosed to the client. ${ }^{147}$ The four other litigation experts all opine that $\$ 5.5$ million was a reasonable fee for LM\&B's work, citing in some instances the LM\&B lawyers' experience and the number of hours they claim to have spent on the case. ${ }^{148}$

However, they do not mention a serious problem with such a claim. It is virtually unheard of to assess the reasonableness of a fee for representation in a civil damage action without any knowledge of either the expected value of the claims or the actual recovery. Yet, it appears that the experts do not have this information because the lawyers have been intent on keeping it secret. The experts do not know whether the attorneys' fee represents 10 percent of the amount LM\&B expected to or did recover for their clients or 10 times that amount. Surely, under the circumstances their opinions cannot be taken seriously.

At the time the DRSA was presented, a similar problem affected disclosure to the clients. The fee was an aggregate sum for representation of all 587 claims. In order to assess its reasonableness (if it had been disclosed), the clients would have needed some sense of the expected aggregate value of the claims. Yet, not only were the clients not provided with any information about claims other than their own, they were forbidden to seek such information. Accordingly, the fee arrangement should be considered unreasonable in form because it did not permit the clients to make a meaningful decision about the reasonableness of its amount.

\section{b. The clients' commitment to stay with LM\&B}

The DRSA provided that, "Each claimant agrees that LM\&B shall be his/her legal representative throughout" the ADR process. ${ }^{149}$ Hazard notes that this is inconsistent with the principle that client is always free to discharge the

147. MOdel Rules of Prof'l CONDUCT R. 1.5(a)-(b) (2002).

148. Nextel Disclosure, supra note 124, at 4-5; LM\&B Supplemental Disclosure, supra note 78 , at $9,17-24,26-27$.

149. DRSA, supra note 81, ๆ 7(a); accord id. Exhibit A, ๆ 1. 
lawyer. He then says only: "The Claimants can make such a commitment on a moral basis but it is not legally binding." 150 Hazard nowhere mentions the lawyers' duty to "fairly describe the client's alternatives" with respect to choice of counsel. ${ }^{151}$ Indeed the knowing inclusion of unenforceable terms in contracts has been held unlawful deception even in arm's length relations. ${ }^{152}$

\section{c. The agreement not to accept or refer other claims}

Hazard opined that LM\&B's agreement not to represent or refer other claimants did not violate the rule against agreement to a "restriction on the lawyer's right to practice [as] part of the settlement of a client controversy."153 He explained that the additional representation "could" involve a prohibited conflict. $^{154}$

In fact, there was no reason to presume that additional representation would involve a conflict, ${ }^{155}$ and even if such a conflict were certain, Hazard's conclusion would not follow. Rule 5.6(b) makes no exception for situations where the agreement to restrict practice would have no practical effect because the practice in question would be independently prohibited. If it had been clear that the conflicts rules would prohibit LM\&B from representing or referring other claimants, there would have been no point to the DRSA restriction. The only possible point of the DRSA restriction was to assure Nextel that, should it prove otherwise permissible for $L M \& B$ to represent or refer future claimants against it, the firm would refuse to do so. Such assurance is precisely what the rule is designed to prohibit.

Hazard also says, "the Agreement contemplates continuing cooperative procedures between LM\&B and Nextel that could be jeopardized if the law firm pursued litigation on terms inconsistent with the Agreement." ${ }^{156}$ Is this any different from arguing that "the agreement does not violate the rule because enforcement of the rule would be inconsistent with the agreement"? In any

150. Hazard, supra note 111.

151. See ABA Comm. on Ethics and Prof'l Responsibility, Formal Op. 99-414 (1999).

152. E.g., Leardi v. Brown, 474 N.E.2d 1094, 1099-1 100 (Mass. 1985).

153. See Model Rules of Prof'L Conduct R. 5.6(b) (2002).

154. Hazard, supra note 111.

155. As support for this claim, Hazard offered only citations to Ortiz v. Fibreboard Corp., 527 U.S. 815 (1999), and Amchem Products, Inc. v. Windsor, 521 U.S. 591 (1997). Hazard, supra note 111. Neither case has any clear relevance to the Nextel situation. In both, the conflicts concerns arose because clients were differently situated in substantive or strategic terms (for example, clients with present as opposed to only potential future claims; class member clients versus individual claimants), and in both there was at least a background concem that the assets available to satisfy the claims were limited so that the gains of one group would only come at the expense of another. In our case, there was no reason to think that new claimants would be differently situated or that their claims would affect the amount available for LM\&B's original clients.

156. Hazard, supra note 111. 
event, the reference to "cooperative procedures between LM\&B and Nextel" as something deserving an exemption from the usual requirements should send a chill down the spine of anyone more sensitive to the dangers posed by this collaboration to LM\&B's clients.

\section{d. The "consultancy" as a restriction on practice}

As we have seen, the main problem with the "consultancy" is that by negotiating a future engagement with the client's adversary before negotiating the clients' claims, LM\&B created a huge conflict of interest. But the agreement is also arguably a "restriction on the lawyer's right to practice," prohibited by Model Rule 5.6(b). This is one issue on which LM\&B's position is defensible, but I mention it because it involves an interesting question.

The usual rationale for the rule is a kind of public utility principle that holds that the lawyer should not without good reason limit his availability to people in need of legal services. There also seems to be a notion that it is unjust and perhaps extortion-like for the lawyer or even the lawyer's current client to take money in return for the lawyer not asserting claims against the payor. ${ }^{157}$

It is an interesting issue whether the rule is violated when, instead of agreeing not to bring claims against the adversary in the future, the lawyer agrees to represent the adversary in the future. Such provisions are common and have been held permissible as part of the settlement of the original client's claims (though not before settlement of these claims). ${ }^{158}$ The rationale for allowing them is that the rule is not intended to prohibit limitations of practice that arise by virtue of representation.

Of course, the objection to this view is that the effect of such agreements is similar to an outright restriction. Once the lawyer represents the (now former) adversary, he will be conflicted out of adverse representations. In most cases, it seems unlikely that the adversary has any other purpose in retaining the plaintiffs' lawyer. Plaintiffs' and defense bars in the tort and employment areas are quite specialized, and businesses rarely retain plaintiffs' lawyers under other circumstances. Indeed, one of LM\&B's experts candidly expresses her understanding that Nextel's reason for entering into the "consultancy" was to preclude LM\&B from further adverse representations. ${ }^{159}$

157. See ABA Comm. on Ethics and Prof'l Responsibility, Formal Op. 93-371 (1993) (noting that one purpose of the rule is to prevent "the use of such agreements [that] may provide clients with rewards that bear less relationship to the merits of their claims than they do to the desire of the defendant to 'buy off' plaintiff's counsel"). For discussion, see Luban, supra note 4 , at $2624-25$.

158. Compare Stephen Gillers \& Richard W. Painter, Free the Lawyers: A Proposal to Permit No-Sue Promises in Settlement Agreements, 18 Geo. J. LeGal ETHICS 291 (2005) (criticizing rule), with David A. Dana \& Susan P. Koniak, Secret Settlements and Practice Restrictions Aid Lawyer Cartels and Cause Other Harms, 2003 U. ILL. L. REV. 1217, 122224 (defending rule).

159. LM\&B Supplemental Disclosure, supra note 78, at 28. 
Many lawyers are untroubled by these provisions, even though broadly permitting them would virtually nullify the prohibition against restrictions on practice in settlements. They are not troubled by nullification because they see the policies behind the rule as weak. The idea of the lawyer as a public utility seems anachronistic or Utopian to them. Moreover, they take the view that was until recently a dogma among federal judges that any practice that promotes settlement carries a large presumption of legitimacy. And they emphasize how difficult it would be to enforce a rule that turned on the motivation of the initially adverse party in asking for the arrangement.

My view is that the policies behind the rule are at least strong enough to support an interpretation that would preclude the lawyer from negotiation of subsequent retention with an adversary until after the conclusion of the initial representation. ${ }^{160}$ This interpretation would be desirable independently on conflicts grounds, would not be hard to apply, and would screen out some pretextual agreements. It would impede settlement only where settlement would be likely to violate the policies of the rule - that is, where settlement is possible only where the defendant offers terms that reflect, not just her valuation of the plaintiffs' claims, but also the deterrence of future claims.

It would not have been unreasonable for Hazard to reject this view, but a responsible appraisal of the DRSA would have at least addressed it.

\section{CONCLUSION}

The defining characteristics of quasi-third-party legal advice - - the absence of a strong duty of care to the ultimate addressees and secrecy-create a market for bad legal advice. Of course, the market does not invariably produce bad advice, but it consistently encourages bad advice.

The market for bad legal advice is a problem for professional and academic morality. Professional responsibility norms are designed to encourage demand for and reliance on legal advice by prescribing safeguards that deter bad advice. However, these norms have largely been preoccupied with first-party advice, and to a smaller extent, traditional explicit third-party advice. However, quasithird-party advice involves the kinds of stakes that have traditionally motivated professional regulation. The advisor invokes the authority of the profession to encourage reliance that has public consequences. The social value of good legal advice is usually understood in terms of enforcement or vindication of law. Bad advice tends to impair enforcement and vindication and to undermine the status and authority of the profession.

When academics give quasi-third-party advice, there is a parallel problem for the academy. Academic norms focus on conduct with respect to scholarship. Quasi-third-party advice usually does not take the form of

160. This position was adopted in In re Conduct of Brandt, 10 P.3d 906, 918 n.13 (Or. 2000) 
scholarship. However, it characteristically invokes the reputation of the university in order to encourage public reliance, and this reliance often has significant public consequences. Quasi-third-party practice is thus in tension with academic norms holding that openness, and especially exposure to peer criticism, is a fundamental safeguard of the soundness of conclusions.

Among several possible responses to these problems, the most promising focus on norms of transparency. Transparency could be imposed in the form of conditions on desired third-party effects, or it could be imposed as academic or professional practice rules. The Article leaves open the question of whether formal, coercive enforcement would be desirable. Even enforced only through informal criticism and shaming, professional and academic transparency requirements could have significant effects. 


\section{APPENDIX I}

[Transcribed]

CHARLES W. WOLFRAM

Charles Frank Reavis Sr.

PROFESSOR OF LAW EMERITUS

CORNELl LAW SCHOOL

10 MYRON TAYLOR HALL

ITHACA, NEW YORK 14853
TELEPHONE: (607) 255-9668

TELECOPIER: (607) 255-7193

March 13, 2002

John K. Villa, Esq.

Williams \& Connolly LLP

725 Twelfth Street N.W.

Washington, D.C. 20005-5901

Dear Mr. Villa:

I have been asked for my opinion on the question whether Vinson \& Elkins acted appropriately in undertaking for Enron a preliminary investigation of the concerns raised by an Enron employee, Sherron Watkins. I enclose my professional resume. In my opinion, Vinson \& Elkins acted both properly and ethically. At your request, I am basing my opinion on the facts set forth in the "Powers Report" (the Report of the Special Committee of the Board of Directors of Enron) and in Vinson \& Elkins' report of its investigation by letter of October 15, 2001.

Ms. Watkins recommended in a letter to CEO Ken Lay that Enron conduct an independent legal and accounting investigation of a number of allegations. She suggested that Vinson \& Elkins not be hired to conduct the investigation because, as she believed, the law firm had provided "true sale" opinions in some of the transactions that she thought should be investigated.

A corporate investigation utilizing independent counsel and an independent auditing firm is a major undertaking. A corporation does not necessarily undertake a full scale independent investigation each time an employee raises a complaint about corporate conduct or the propriety of the corporation's accounting. Before initiating such an independent investigation, it is customary and appropriate for a corporation to conduct a preliminary inquiry to determine whether such an independent investigation is warranted. From my review of Vinson \& Elkins' report of October 15, 2001 and the Powers Report, it is clear that the law firm undertook and conducted a preliminary inquiry and not the 
type of full independent investigation that Ms Watkins requested, and that such an inquiry was precisely what its client, Enron, had requested.

The standard for determining whether Vinson \& Elkins could undertake such a preliminary investigation was whether the law firm had a conflict of interest under the Texas Disciplinary Rules of Professional Conduct. To answer that question, it is necessary to examine the specific issues that Enron asked Vinson \& Elkins to investigate.

The Powers Report states that Ms. Watkins "raised serious questions concerning the accounting treatment and economic substance" of certain transactions. p. 172. According to CEO Lay, as noted in the Powers Report, Ms. Watkins' major focus was Raptor, a series of transactions on which Enron faced an impending credit problem in 2002 and 2003. As quoted in the Powers Report, Ms. Watkins' letter also stated that "Enron has been very aggressive in its accounting-most notably in the Raptor transactions." Powers Report p. 172 (quoting letter).

The purpose of Vinson \& Elkins' preliminary investigation was to determine whether Ms. Watkins had raised issues sufficient to warrant a fullscale investigation of the nature that she had suggested. As agreed with Enron, Vinson \& Elkins' "review would not include questioning the accounting treatment and advice from Anderson, or a detailed review of individual LJM transactions." Powers Report p. 173. "Instead, Vinson \& Elkins would conduct a 'preliminary investigation' which was defined as determining whether the facts raised by Watkins warranted further independent legal or accounting review." p. 173. Vinson \& Elkins could reasonably agree to conduct a preliminary inquiry of this nature and scope.

My review of Ms. Watkins' letter, the Powers Report, and the Vinson \& Elkins report establishes that, as agreed with its client, Vinson \& Elkins' investigation focused on whether Ms. Watkins had raised new facts regarding the issues of business and accounting judgment cited in her letter and supplementary materials, not on the quality of the legal work previously performed for Enron by Vinson \& Elkins. There was no conflict of interest for Vinson \& Elkins to undertake such an investigation because it would not be sitting in judgment of its own legal services.

Enron's annual payment of millions in legal fees for many matters to Vinson \& Elkins over an extended period prior to the time of the investigation did not create a conflict of interest for Vinson \& Elkins. It is quite common for companies to call on their primary outside counsel with whom they do the most work in such circumstances. This investigation was not a full "independent counsel" investigation in the sense, for example, of the investigation conducted by the lawyers who assisted in preparing the Powers Report. Neither Enron nor Vinson \& Elkins regarded it as such an "independent counsel" investigation, and that was reasonable under the circumstances.

Although Vinson \& Elkins has been criticized for accepting the word of the people it interviewed in the investigation, it bears noting that Vinson \& Elkins, 
like any lawyer, may properly assume that its client is telling the truth absent evidence to the contrary. Vinson \& Elkins could also rely on the accountants, Board members, employees, and officers who knew of the transactions and the accounting treatment of the transactions.

In summary, it is my opinion based on the Powers Report and Vinson \& Elkins' Report that:

- There was no conflict of interest in Vinson \& Elkins' conducting a preliminary inquiry into the concerns raised by Sherron Watkins.

- Enron and Vinson \& Elkins could properly limit the preliminary inquiry to whether the facts justified a full scale "independent" investigation.

- The fact that Vinson \& Elkins had previously earned millions of dollars in fees from Enron did not disqualify it from ethically conducting a preliminary investigation of the kind often performed by the main outside counsel for corporations.

- Vinson \& Elkins could properly accept the word of the officers of its client and rely on the judgment of the accountants, Board members, employees, and officers in reaching its conclusions.

- It would be highly unusual for a law firm in the position of Vinson \& Elkins to decline in these circumstances to undertake such a preliminary investigation on ethical grounds. It is customary for clients like Enron to turn to large law firms that are acquainted with the company's business and transactions to conduct preliminary investigations and make recommendations, such as Vinson \& Elkins was asked to do here.

- I find no breach of any ethical rule by Vinson \& Elkins in accepting and conducting the preliminary review of the concerns raised by Sherron Watkins.

Very truly yours,

Charles W. Wolfram 
[Transcribed]

Appendix II

TRUSTEE PROFESSOR OF LAW
UNIVERSITY OF PENNSYLVANIA
3400 CHESTNUT STREET
PHILADELPHIA, PA 19104
TELEPHONE: 215-898-7494

GEOFFREY C. HAZARD, JR.

TRUSTEE PROFESSOR OF LAW

CONSULTING OFFICE ADDRESS

513 CEDAR LANE

SWARTHMORE, PA 19081

TELEPHONE: 610-544-4550

FAX: 610-544-5083

September 28, 2000

Mary Elizabeth McGarry, Esq.

Simpson Thacher \& Bartlett

425 Lexington Avenue

New York, New York 10017-3954

Re: Nextel Communications, Inc.

Dear Ms. McGarry:

This responds to your request for my opinion concerning the propriety, under the rules of professional ethics in New York, Virginia and other jurisdictions, of the arrangement set forth in the September 28, 2000 Draft Confidential agreement, and related proposed documentation (collectively, "Agreement"), a copy of which you have sent me.

The proposed Agreement includes a detailed Alternative Dispute Resolution procedure for resolving claims by claimants ("Claimants") of employment discrimination in employment or application for employment with Nextel Communications, Inc. and its affiliates ("Nextel"), who are represented by the law firm of Leeds Morelli \& Brown ("Leeds Morelli"). Several hundred Claimants are involved. The Agreement calls for processing the claims of the Claimants on a measured but expedited basis, through a dispute resolution process involving an interview and negotiation, mediation if necessary and binding arbitration if necessary. The Agreement contemplates that Leeds Morelli and Nextel will proceed cooperatively to process the claims, including mutual exchange of information concerning the claims, through the three-stage procedure, culminating in an agreed-upon resolution or a determination though arbitration and a General Release by any Claimant receiving any award.

Under the Agreement, Nextel will pay to Leeds Morelli agreed amounts in lieu of the attorneys' fees and expenses that the Claimants would otherwise be obligated to pay Leeds Morelli. 
The Agreement further expresses the intention of Leeds Morelli not to accept representation of other persons with similar claims against Nextel outside the framework of the Agreement, and obligates Leeds Morelli to refrain from referring to other lawyers' prospective claimants who may inquire with Leeds Morelli.

The parties believe that the dispute resolution process will benefit both the Claimants and Nextel. The fee to be paid the law firm takes account of the fact that the firm will have to engage in a large and expensive staffing arrangement in order to present and process the claims on the expedited basis.

In addition, the Agreement calls for engagement of Leeds Morelli by Nextel, after completion of the dispute resolution process for all of the Claimants represented by Leeds Morelli, to serve as a consultant and provide assistance and legal advice with regard to equal employment and affirmative action matters. Nextel, which is presently an adversary of these Claimants, will thereupon become a client of the firm representing the Claimants. This engagement can benefit present and future Nextel employees, as well as Nextel itself, by providing objective and experienced guidance in the company's handling of employee relations.

The Agreement has other provisions concerning the arrangements among Claimants, Leeds Morelli and Nextel, some of which are noted below.

The Agreement contemplates that the payment by Nextel to Leeds Morelli of an amount for attorneys fees and expenses will be disclosed to the Claimants and their consent obtained. Such a disclosure and informed consent is required. See New York DR 5-107(a), the provisions of which correspond to counterpart rules in Virginia, Va. Code of Prof. Responsibility, Rule 1.8(f), and all other jurisdictions. See American Bar Association, Model Rules of Professional Conduct, Rule 1.8(f). I assume that Leeds Morelli has and will continue to exercise independent professional judgment on behalf of the Claimants, in reaching and implementing the Agreement. On that basis, and upon disclosure and informed consent, the payments arrangement is in my opinion compatible with the foregoing ethical standards.

The contemplated agreement whereby Leeds Morelli will refrain from undertaking representation of other claimants outside the framework of the Agreement is, in my opinion, compatible with applicable ethical standards, having regard for circumstances involved. Generally, a lawyer may not agree to refrain from representation of other potential clients in connection with settlement of a controversy on behalf of a client. See New York DR 2-108(B). Virginia's rule is less restrictive. See Va. Code of Prof. Resp. Rule 5.6(b) However, in the present situation the representation of the Claimants under the Agreement could well constitute a conflict of interest with other potential clients, in light of the decisions of the United States Supreme Court in Ortiz v. Fibreboard Inc., 527 U.S. 815 (1999), and Amchem Products, Inc. v. Windsor, 521 U.S. 591 (1997). Such a conflict could result in jeopardy to the settlements under the Agreement, and thus be disadvantageous both to Nextel and, 
eventually, to various Claimants. In addition, the Agreement contemplates continuing cooperative procedures between Leeds Morelli and Nextel that could be jeopardized if the law firm pursued litigation on terms inconsistent with the Agreement. In these circumstances, in my opinion the agreement by Leeds Morelli does not improperly "restrict" the firm's right to practice within the intendment of New York DR 2-108(B). For the same reason it does not constitute a "broad restriction" on Leeds Morelli, see Va. Code of Prof. Resp., Rule 5.6(b). The Leeds Morelli agreement not to refer to other lawyers any potential claimants who make inquiry of the firm falls in the same category.

The contemplated arrangement whereby Nextel will engage Leeds Morelli after the claims are resolved is set forth in the proposed Agreement and hence will be made prior to conclusion of the settlement process. The prospect of such employment would involve a conflict of interest on the part of the Leeds Morelli firm. See New York DR 5-105(a); Va. Code of Prof. Resp., Rule 1; ABA Model Rule 1.7. However, in my opinion it is a "consentable" conflict, i.e., a conflict that may be waived by the affected clients. Obviously, Nextel will not become a client until the settlements are resolved. However, the individual Claimants are present clients of the Leeds Morelli firm and their informed consents should be obtained.

The consents should address both of the arrangements, i.e., the payment in lieu of the Claimants' attorneys fee and expenses and the contemplated subsequent employment of Leeds Morelli by Nextel.

It is not obligatory that the consents of the claimants represented by Leeds Morelli be in writing, except in a few jurisdictions such as California. However, the Agreement appropriately calls for the consents to be in writing, partly as protection against misunderstanding and subsequent dispute but also to impress on the clients that a substantial matter is involved.

You have inquired whether the payment in lieu of the Claimants' attorneys fees and expenses may be made through one fund rather than in separate payments. In my opinion the method of payment is a matter of convenience, so long as the fact of the payments is disclosed and made the basis of a consent on the part of the affected Claimants.

In addition, I note the following provisions of the proposed Agreement:

First, the Agreement provides that the claim and resolution of each Claimant is not to be disclosed to other Claimants. In my opinion this is proper. The procedure and substance of the arrangement under the proposed Agreement is not an "aggregate settlement" within the meaning of New York DR 5-106(A); Va. Code Prof. Resp., Rule 1.8(g); and ABA Model Rule 1.8(g). An "aggregate settlement" is one in which a fixed sum is to be divided among two or more claimants. In such a settlement, fairness to the participants requires that each one know the allocation made to the others. The procedure under the proposed Agreement, in contrast, calls for separate settlement or resolution of each Claimant's claim on its own footing. Accordingly, in my opinion the rule concerning disclosure in aggregate settlements has no application. 
Second, the form of Individual Agreement sets forth a consent by the Claimant executing such a document to the conflicts described above. Such a consent is valid only if predicated on adequate disclosure. I assume that Leeds Morelli will provide such a disclosure. The disclosure should be in writing for any claimant who is a resident of California.

Third, the Agreement calls for the Claimants to continue engagement of Leeds Morelli through the whole ADR process. The Claimants can make such a commitment on a moral basis but it is not legally binding. A client has authority to discharge a lawyer at any time, for any reason or no reason. There are decisions suggesting that this right of discharge may not be infringed by imposition of adverse consequences to a client who exercises the right. I express no opinion whether the provisions on this subject in the proposed Agreement constitute such an infringement. I recommend that the disclosure and consent by the Claimants address this issue.

Sincerely,

Geoffrey C. Hazard, Jr. 
